\title{
Targeting Divalent Metal Cations with Re(I) Tetrazolato Complexes
}

\author{
Valentina Fiorini, ${ }^{\text {a }}$ Anna Maria Ranieri, ${ }^{\text {a }}$ Sara Muzzioli, ${ }^{a}$ Karen D. M. Magee, ${ }^{\mathrm{b}}$ Stefano Zacchini, \\ Nurshadrina Akabar, ${ }^{\mathrm{b}}$ Alessandra Stefan, ${ }^{\mathrm{c}}$ Mark I. Ogden, ${ }^{\mathrm{b}}$ Massimiliano Massi, ${ }^{\mathrm{b}}$ Stefano Stagni $*^{\mathrm{a}}$
}

${ }^{a}$ Department of Industrial Chemistry "Toso Montanari”, University of Bologna, Viale Risorgimento 4, I-40136 Bologna, Italy

${ }^{b}$ Nanochemistry Research Institute, Department of Chemistry, Curtin University, GPO Box U 1987, Perth, Australia, 6845

${ }^{c}$ Department of Pharmacy and Biotechnology, University of Bologna, Viale Risorgimento 4, I40136 Bologna, Italy

e-mail: stefano.stagni@unibo.it (Stefano Stagni), m.massi@curtin.edu.au (Massimiliano Massi)

\begin{abstract}
In order to exploit their potential as versatile luminescent sensors, four new Re(I)-tetrazolato complexes with the general formula $f a c$ - $\left[\operatorname{Re}(\mathrm{CO})_{3}(\operatorname{diim})(\mathbf{L})\right]$, where diim is by 2,2'-bipyridine (bipy) or 1,10-phenanthroline (phen) and $\mathbf{L}^{-}$ is either the anion 5-(2'-pyridyl)tetrazolato (2-PTZ) or 5-(2'-quinolyl)tetrazolato (2-QTZ'), were prepared and fully characterized. In all cases, the regioselective coordination of the $\operatorname{Re}(\mathrm{I})$ center through the N-2 atom of the tetrazolato ring was observed. This particular feature ensures the availability of the diiminic $\left(\mathbf{N}^{\wedge} \mathbf{N}\right)$ site that was systematically incorporated into the structure of the 2-PTZ and 2-QTZ ligands for the further coordination with metal cations. Such a diimine-type coordination mode was preliminarily tested by using the mononuclear $\operatorname{Re}(\mathrm{I})$ complexes as $\mathbf{N}^{\wedge} \mathbf{N}$ ligands for the preparation of two $\left[\left(\mathbf{N}^{\wedge} \mathbf{N}\right) \mathrm{Cu}(\mathbf{P O P})\right]$ cationic species, where POP is the chelating diphosphine bis[2(diphenylphosphino)phenyl]ether. The X-ray structures of the resulting $\operatorname{Re}(\mathrm{I})-\mathrm{Cu}(\mathrm{I})$ dyads revealed that the $\operatorname{Re}(\mathrm{I})$ mononuclear complexes effectively behaved as chelating $\mathbf{N}^{\wedge} \mathbf{N}$ ligands with respect to the $[\mathrm{Cu}(\mathbf{P O P})]^{+}$fragment, the coordination of which also resulted in the significant modification of the $\operatorname{Re}(\mathrm{I})$-centered luminescence. With these data in hand, the luminescent sensing abilities of the four new $\operatorname{Re}(\mathrm{I})$ tetrazolato complexes were screened with respect to divalent metal ions of toxicological and biological importance such as $\mathrm{Zn}(\mathrm{II}), \mathrm{Cd}(\mathrm{II})$ and $\mathrm{Cu}(\mathrm{II})$. The interaction of the $\operatorname{Re}(\mathrm{I})$ complexes with $\mathrm{Zn}(\mathrm{II})$ and $\mathrm{Cd}(\mathrm{II})$ was witnessed by the evident blue shift $\left(\Delta \lambda_{\max }=22-36 \mathrm{~nm}\right)$ of the emission maxima, which was also accompanied by a significant elongation of the emission lifetimes. On the contrary, the addition of the cupric ion caused the substantial quenching of the radiative processes originating from the Re(I) luminophores
\end{abstract}




\section{Introduction}

The prevalent charge transfer character that connotes the nature of the emissive excited states of facial tricarbonyl $\operatorname{Re}(\mathrm{I})$ diimine species (e.g. metal-to-ligand charge transfer of triplet spin multiplicity, ${ }^{3} \mathrm{MLCT}$ ) is one of the key factors that have favoured the development of this class of compounds as precursor for emissive materials as well as luminescent probes for sensing. ${ }^{1}$ Various classes of analytes have been investigated in relation to how they modulate the specific photophysical properties upon interaction with the rhenium complexes. These species range from the most simple electrophile $\mathrm{H}^{+}$, alkali and transition metal cations, to biologically relevant macromolecules such as proteins and DNA. In all cases, the detection of such analytes is related to the variation of the luminescent output of the $\operatorname{Re}(\mathrm{I})$ chemosensors that occurs upon the perturbation of the chemical or physical parameters of their surrounding environment. ${ }^{2}$ On such basis, a considerable research effort has been devoted to the design of numerous $\operatorname{Re}(\mathrm{I})$-based luminescent complexes in which the development of their sensing abilities toward specific targets has been combined with the improvement of their affinity to cellular substrates in terms of, for example, cellular uptake and specific organelle localization. ${ }^{3}$ We have recently contributed to this research framework by describing synthesis, photophysical properties, ${ }^{4}$ the reactivity toward electrophiles, ${ }^{5}$ and biological behaviour ${ }^{6}$ of a family of neutral $f a c-\left[\operatorname{Re}(\operatorname{diim})(\mathrm{CO})_{3}(\mathbf{L})\right]$, where diim represents a conventional diimine ligand such as 1,10-phenanthroline (phen) or 2,2'-bipyridine (bipy) and L is a monodentate 5-aryl tetrazolato ancillary ligand (Scheme 1). With this class of complexes, we have in fact demonstrated the first example of direct staining of neutral lipid droplets in live Drosophila and human adipose 3T3-L1 cell lines, highlighting how facile chemical modifications of the ancillary ligands can be exploited to confer the complexes with defined cellular specificity without the need for bioconjugation. ${ }^{6}$

From the point of view of the luminescence properties, these neutral $\operatorname{Re}(\mathrm{I})$-tetrazolato complexes display bright phosphorescent emission that originate from admixtures of ${ }^{3}$ MLCT and ${ }^{3}$ LLCT (ligand-to-ligand charge transfer) excited states, with a significant contribution from the tetrazolato heterocycle in determining the composition of HOMO-type orbitals. ${ }^{4}$ As a consequence, the luminescent output of these complexes could be efficiently modulated by lowering the electron-rich nature of the tetrazolato via reaction with electrophilic reagents such as $\mathrm{H}^{+}$and $\mathrm{CH}_{3}{ }^{+}$. In fact, the reversible protonation or irreversible methylation caused a marked blue shift of emission maxima $\left(\Delta \lambda_{\max } c a .50 \mathrm{~nm}\right)$ with a concomitant 6-10 fold increase of quantum yield and the extension of the emissive lifetime from few hundreds of nanoseconds to microseconds. ${ }^{5}$ Prompted by these results, we have decided to investigate the possibility of improving the sensitivity of this class of rhenium complexes to divalent transition metal ions of biological and/or toxicological importance. To this 
extent, we have prepared a series of four $\operatorname{Re}(\mathrm{I})$ tetrazolato complexes, where the tetrazolato heterocycle is conjugated to either 2'-pyridine (2-PTZ) or 2'-quinoline (2-QTZ) in order to introduce a diimine-type coordination vacancy (Scheme 1). The detailed description of the synthesis, structural features and optical properties of these $\operatorname{Re}(\mathrm{I})$ species is reported herein, including an investigation into their sensing capacity towards $\mathrm{Zn}^{2+}, \mathrm{Cd}^{2+}$ and $\mathrm{Cu}^{2+}$, which are used as exemplar biological species.

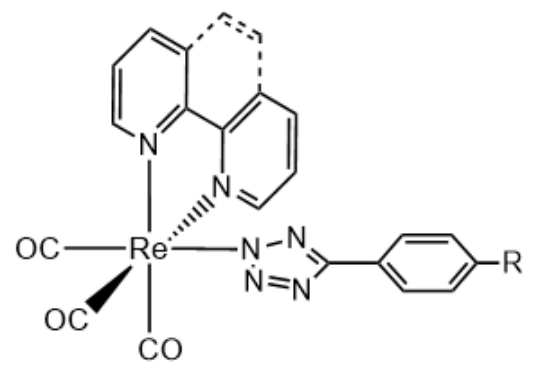

fac-[Re(diim) $\left.(\mathrm{CO})_{3}(\mathrm{~L})\right]$

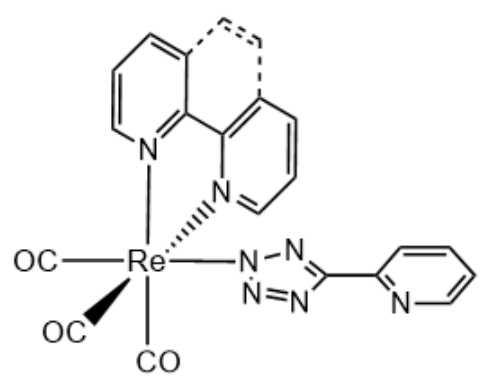

fac-[Re(diim) $\left.(\mathrm{CO})_{3}(2-\mathrm{PTZ})\right]$

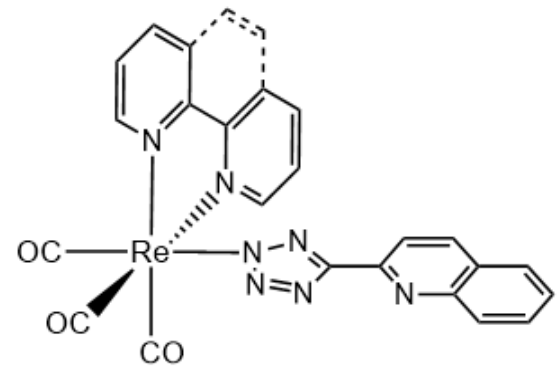

fac-[Re(diim)(CO) $3(2-Q T Z)]$

Scheme 1. General formulation of the $f a c-\left[\operatorname{Re}(\operatorname{diim})(\mathrm{CO})_{3}(\mathbf{L})\right]$ complexes described in this work, where diim represents 1,10 phenanthroline (phen) or 2,2' bipiridine (bipy) and (L) is the 2-pyridyl tetrazolato (2-PTZ) or 2quinolyl tetrazolato (2-QTZ) anion. 


\section{Results and Discussion}

Synthesis and spectroscopic characterization of the complexes

The tetrazole ligands 2-PTZH and 2-QTZH have been obtained by following two well established methods reported in the literature, ${ }^{8}$ which both involved the 1,3 dipolar cyclization reaction of the azide anion $\left(\mathrm{N}_{3}{ }^{-}\right)$with the corresponding nitrile precursors 2-cyanopyridine or 2-cyanoquinoline, respectively.

The neutral $\operatorname{Re}(\mathrm{I})$ complexes have been prepared by a simple metathesis between fac-

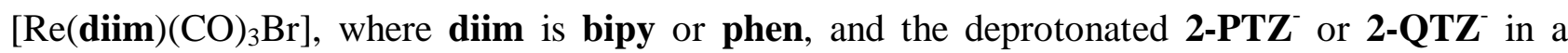
refluxing 3:1 ethanol/water mixture (Scheme 2). ${ }^{4}$ This methodology is very convenient, as the targeted complexes precipitate out of solution and require a simple filtration to be isolated.

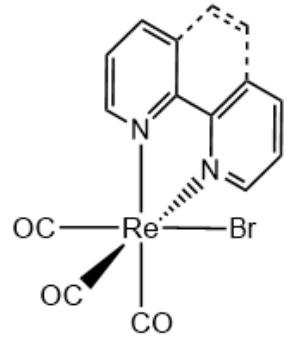

fac-[Re( $\left.\operatorname{diim})(\mathrm{CO})_{3}(\mathrm{Br})\right]$

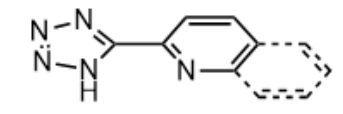

2-PTZH or 2-QTZH

$\mathrm{Et}_{3} \mathrm{~N}$

$\mathrm{EtOH} / \mathrm{H}_{2} \mathrm{O} 3: 1$

Reflux, 24 hrs

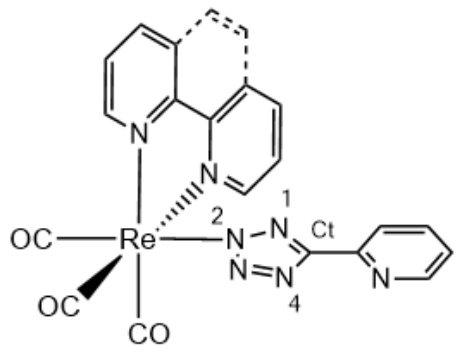

fac-[Re(diim)(CO) $\left.)_{3}(2-P T Z)\right]$

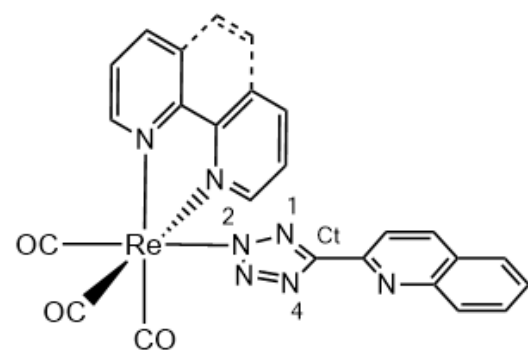

fac-[Re(diim) $\left.(\mathrm{CO})_{3}(2-\mathrm{QTZ})\right]$

Scheme 2. Synthetic procedure for the preparation of the Re(I) tetrazolato complexes

Infrared (IR) spectroscopy from dichloromethane solutions (see ESI, table S1) provided results congruent with neutral $\operatorname{Re}(\mathrm{I})$ complexes with facial configuration of the three $\mathrm{CO}$ ligands. The carbonyl stretching region shows one sharp band centred at $c a .2030 \mathrm{~cm}^{-1}$, assigned to the totally symmetric in-phase stretching $\mathrm{A}^{\prime}(1)$, and a broader band at $c a .1922 \mathrm{~cm}^{-1}$, which results from the superimposition of the totally symmetric out-of-phase stretching $\mathrm{A}^{\prime}(2)$ and the asymmetric stretching $\mathrm{A}^{\prime \prime}$. 
Whereas the ${ }^{1} \mathrm{H}$ NMR spectra of the neutral Re(I) complexes all displayed the patterns of signals that were expected from the presence of one symmetrical diimine ligand and one axially coordinated tetrazolato anion, the analysis of the ${ }^{13} \mathrm{C}$ NMR spectra provided indications about the coordination binding mode of the tetrazolato ligand. ${ }^{9,10}$ For each complex, one single tetrazolato carbon resonance $(\mathrm{Ct}, \delta \mathrm{C}=c a .163 \mathrm{ppm})$ was observed within the chemical shifts range 160-165 ppm (see ESI, figures S1-S10). This value is diagnostic for the regioselective coordination of the $\operatorname{Re}(\mathrm{I})$ fragment through the N-2 atom of the tetrazolato ring (see Scheme 2 for atom numbering), ${ }^{4}$ as further confirmed by X-ray diffraction data.

In order to assess the binding capacity of the tetrazolato diiminic site, we have employed the complexes $f a c$ - $\left[\operatorname{Re}(\right.$ bipy $)(\mathrm{CO})_{3}$ 2-PTZ $\left.)\right]$ and $f a c$ - $\left[\operatorname{Re}(\right.$ bipy $)(\mathrm{CO})_{3} \mathbf{2}$-QTZ)] as the neutral $\mathbf{N}^{\wedge} \mathbf{N}$ ligands for $\mathrm{Cu}(\mathrm{I})$. In particular, we have targeted the cationic species $\left[\left(\mathbf{N}^{\wedge} \mathbf{N}\right) \mathrm{Cu}(\mathrm{POP})\right]^{+}$, herein referred to as $[\mathbf{R e}-(\mathbf{2}-\mathbf{P T Z})-\mathbf{C u}]^{+}$and $[\mathbf{R e}-(\mathbf{2}-\mathbf{Q T Z})-\mathbf{C u}]^{+}$, where POP is the chelating diphosphine bis[2-(diphenylphosphino)phenyl]ether (Scheme 3). By following the same procedure that we have reported for the preparation of analogous tetrazole-based $\mathrm{Cu}(\mathrm{I})$ cationic derivatives, ${ }^{11}$ the targeted $\operatorname{Re}(\mathrm{I})-\mathrm{Cu}(\mathrm{I})$ dyads were isolated and their structures was confirmed by X-ray diffraction.

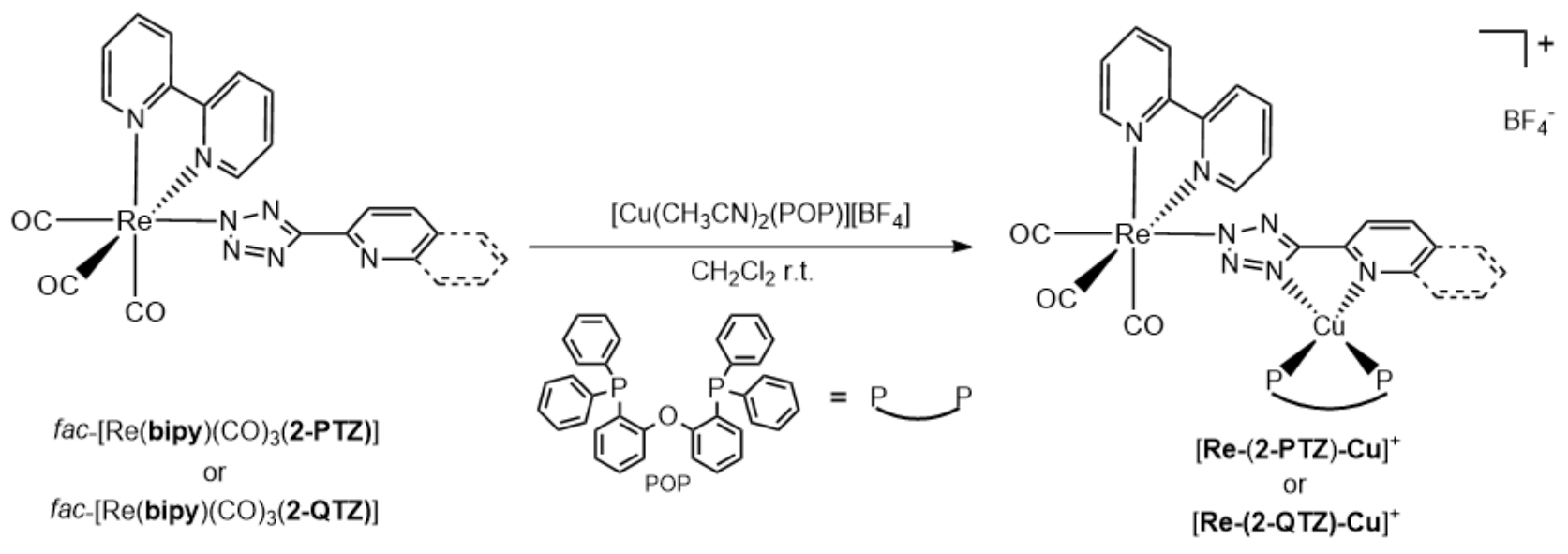

Scheme 3. Synthetic procedure for the preparation of the dinuclear species $[\mathbf{R e}-(\mathbf{2}-\mathbf{P T Z})-\mathbf{C u}]^{+}$and $[\mathbf{R e}-(\mathbf{2}-\mathbf{Q T Z})-\mathbf{C u}]^{+}$. 
The structures of $f a c-\left[\operatorname{Re}(\mathbf{b i p y})(\mathrm{CO})_{3}(\mathbf{2}-\mathbf{P T Z})\right], \quad f a c-\left[\operatorname{Re}(\mathbf{p h e n})(\mathrm{CO})_{3}(\mathbf{2}-\mathbf{P T Z})\right] \quad$ and $\quad f a c-$ $\left[\operatorname{Re}(\mathbf{p h e n})(\mathrm{CO})_{3}(\mathbf{2}-\mathbf{Q T Z})\right] \cdot 0.5 \mathrm{CH}_{2} \mathrm{Cl}_{2}$ have been determined by single crystal X-ray diffraction studies (Figures 1-3). Their structures and bonding parameters closely resemble those previously reported for analogous $f a c-\left[\operatorname{Re}(\operatorname{diim})(\mathrm{CO})_{3}(\mathbf{L})\right]$ complexes $(\mathbf{d i i m}=$ bipy, phen; $\mathbf{L}=$ tetrazolato ligands). ${ }^{4 a}$ Thus, the Re centers display an octahedral geometry being coordinated to three CO ligands (in a facial arrangement), a cis-chelating diimine ligand (bipy or phen) and a substituted tetrazolato ring bonded to the metal through its $\mathrm{N} 2$ atom.

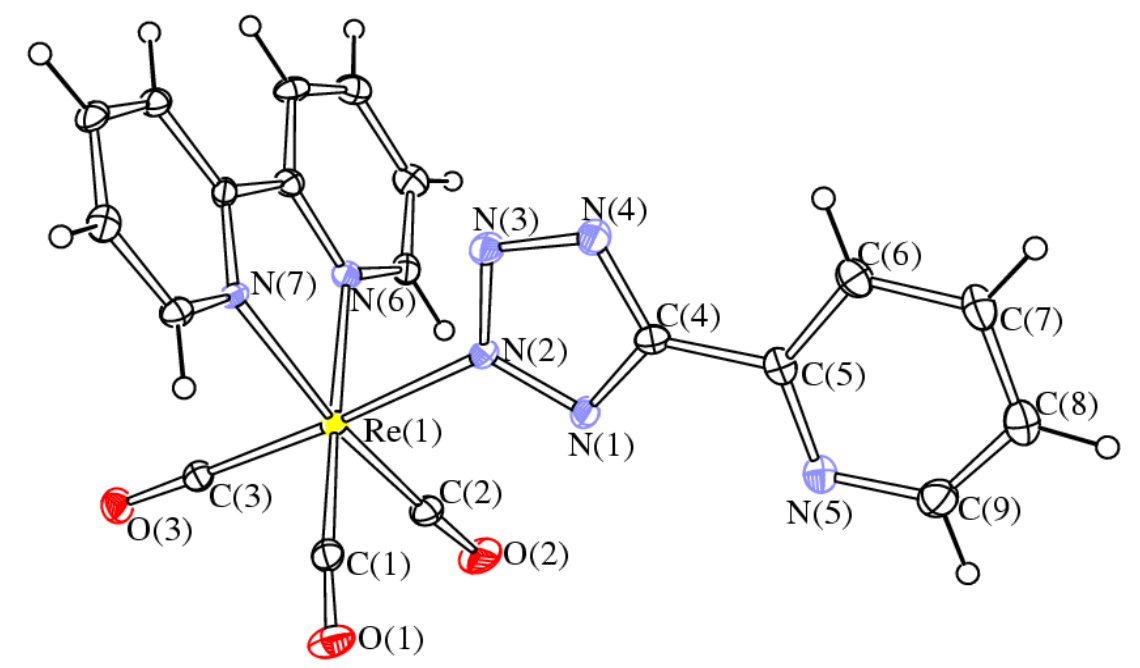

Figure 1. Molecular structure of $f a c-\left[\operatorname{Re}(\right.$ bipy $\left.)(\mathrm{CO})_{3}(2-\mathbf{P T Z})\right]$ with key atoms labelled. Displacement ellipsoids are at the $30 \%$ probability level. Selected bond lengths $(\AA)$ and angles (deg): $\operatorname{Re}(1)-C(1) 1.919(6), \operatorname{Re}(1)-C(2) 1.920(6)$, $\mathrm{Re}(1)-\mathrm{C}(3)$ 1.926(6), Re(1)-N(2) 2.170(5), Re(1)-N(6) 2.156(5), Re(1)-N(7) 2.174(4), N(1)-N(2) 1.340(7), N(2)-N(3) 1.345(6), N(3)-N(4) 1.327(7), N(4)-C(4) 1.347(7), N(1)-C(4) 1.332(7), C(4)-C(5) 1.482(8), N(6)-Re(1)-N(7) 75.21(17), $\mathrm{C}(1)-\operatorname{Re}(1)-\mathrm{N}(6) 175.0(2), \mathrm{C}(2)-\operatorname{Re}(1)-\mathrm{N}(7)$ 170.6(2), C(3)-Re(1)-N(2) 174.6(2). 


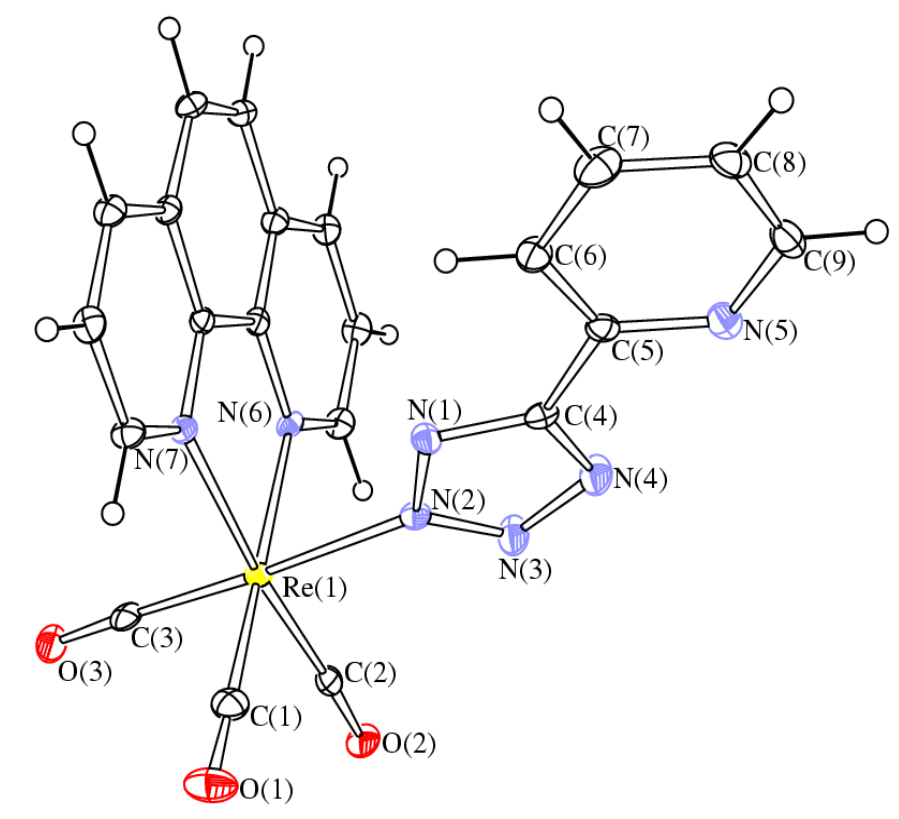

Figure 2. Molecular structure of $f a c-\left[\operatorname{Re}(\mathbf{p h e n})(\mathrm{CO})_{3}(\mathbf{2}-\mathbf{P T Z})\right]$ with key atoms labelled. Displacement ellipsoids are at the 30\% probability level. Selected bond lengths (Å) and angles (deg): $\operatorname{Re}(1)-C(1) 1.915(4), \operatorname{Re}(1)-C(2) 1.924(4)$, Re(1)-C(3) 1.927(4), Re(1)-N(2) 2.179(3), Re(1)-N(6) 2.169(3), Re(1)-N(7) 2.174(3), N(1)-N(2) 1.342(4), N(2)-N(3) 1.311(4), N(3)-N(4) 1.339(5), N(4)-C(4) 1.340(4), N(1)-C(4) 1.329(5), C(4)-C(5) 1.479(5), N(6)-Re(1)-N(7) 76.10(10), C(1)-Re(1)-N(6) 172.57(13), C(2)-Re(1)-N(7) 172.47(14), C(3)-Re(1)-N(2) 176.42(14).

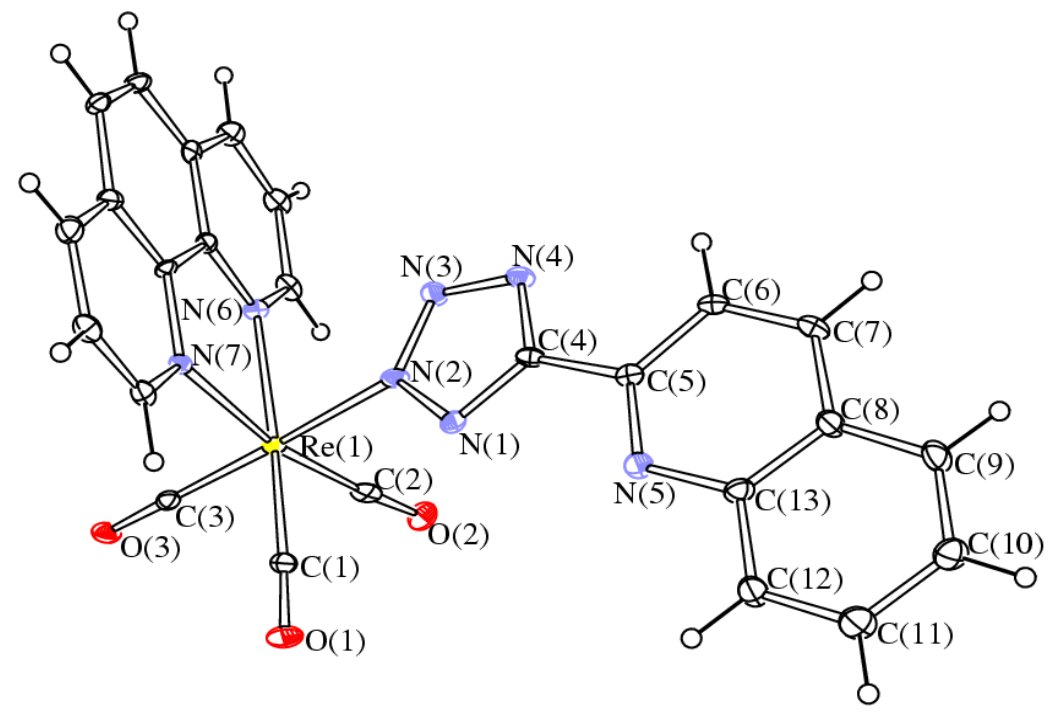

Figure 3. Molecular structure of $f a c$ - $\left[\operatorname{Re}(\mathbf{p h e n})(\mathrm{CO})_{3}(\mathbf{2}-\mathbf{Q T Z})\right]$ with key atoms labelled. Displacement ellipsoids are at

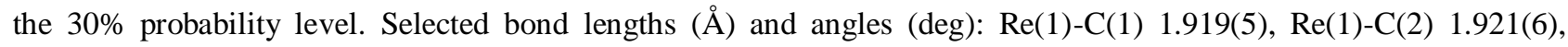
Re(1)-C(3) 1.929(6), Re(1)-N(2) 2.163(5), Re(1)-N(6) 2.182(4), $\operatorname{Re}(1)-\mathrm{N}(7) 2.161(5), \mathrm{N}(1)-\mathrm{N}(2)$ 1.350(5), N(2)-N(3) 1.329(6), N(3)-N(4) 1.331(6), N(4)-C(4) 1.358(6), N(1)-C(4) 1.333(6), C(4)-C(5) 1.468(7), N(6)-Re(1)-N(7) 75.83(16), $\mathrm{C}(1)-\operatorname{Re}(1)-\mathrm{N}(6)$ 173.0(2), C(2)-Re(1)-N(7) 169.40(19), C(3)-Re(1)-N(2) 178.2(2). 
The structures of the $[\mathbf{R e}-2-\mathbf{P T Z}-\mathbf{C u}]\left[\mathrm{BF}_{4}\right] \cdot 2 \mathrm{Et}_{2} \mathrm{O}$ and $[\mathbf{R e}-2-\mathbf{Q T Z}-\mathbf{C u}]\left[\mathrm{BF}_{4}\right] \cdot 1.67 \mathrm{CH}_{2} \mathrm{Cl}($ Figures 4 and 5) reveal the expected coordination of the $\mathrm{Cu}(\mathrm{I})$ center to the diiminic site the tetrazolato ligands via the tetrazolic N4 and heterocyclic 2-pyridyl or 2 quinolyl $\mathrm{N}$ atoms. The $\mathrm{Cu}(\mathrm{I})$ center displays a distorted tetrahedral geometry as previously found in analogous complexes. ${ }^{11,12,13}$ The

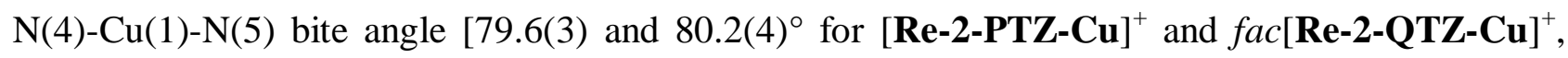
respectively] is very close to the one found in $\left[\mathrm{Cu}\left(\mathrm{N}^{\wedge} \mathrm{N}\right)(\mathrm{POP})\right]^{+}\left[78.6(2)^{\circ}\right] .{ }^{11}$ The $\mathrm{P}(1)-\mathrm{Cu}(1)-\mathrm{P}(2)$ angle [109.61(9) and $111.26(12)^{\circ}$ ] is in the usual range for a chelating POP ligand, which normally displays a rather large natural bite angle. ${ }^{14}$

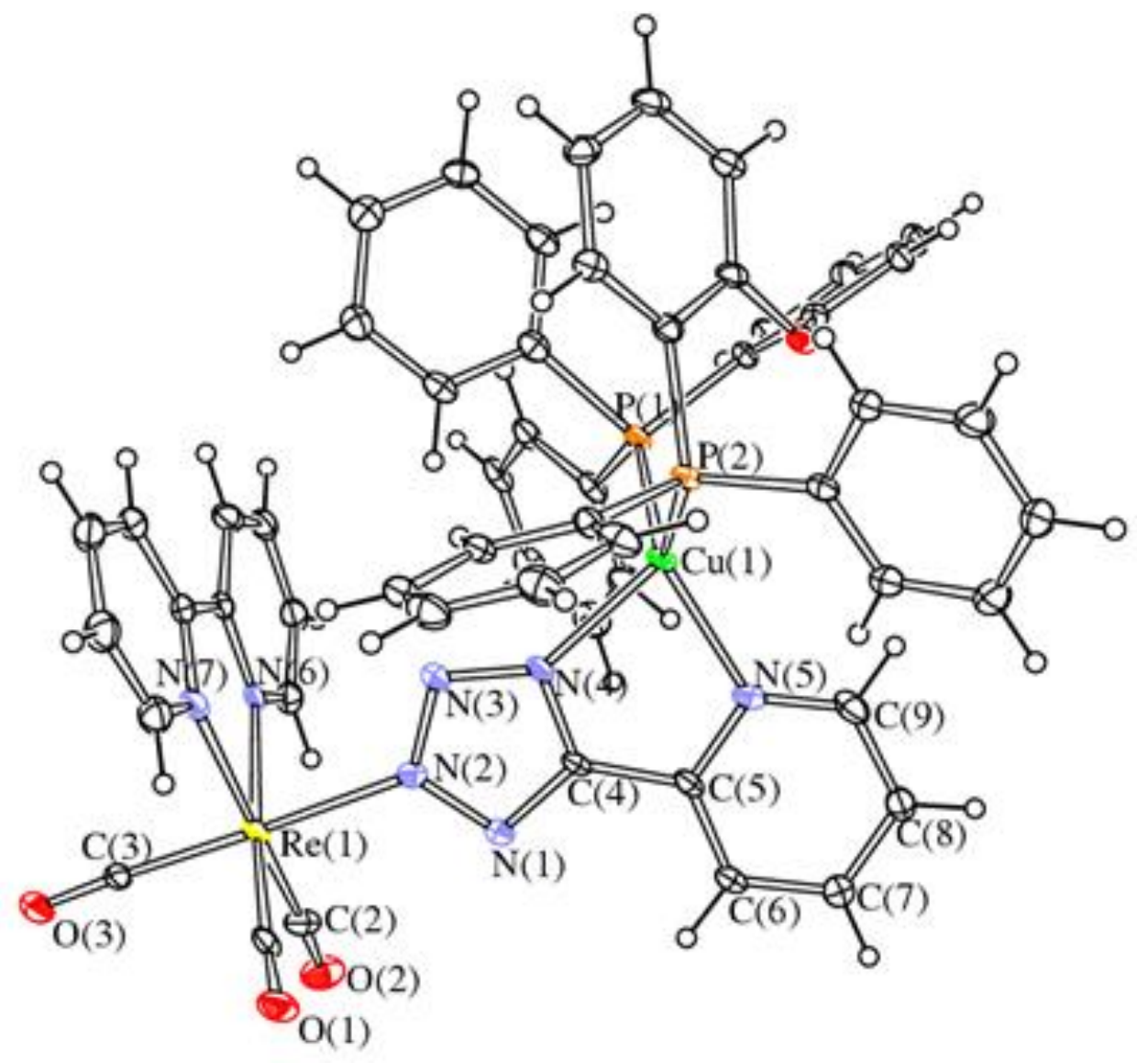

(a) 


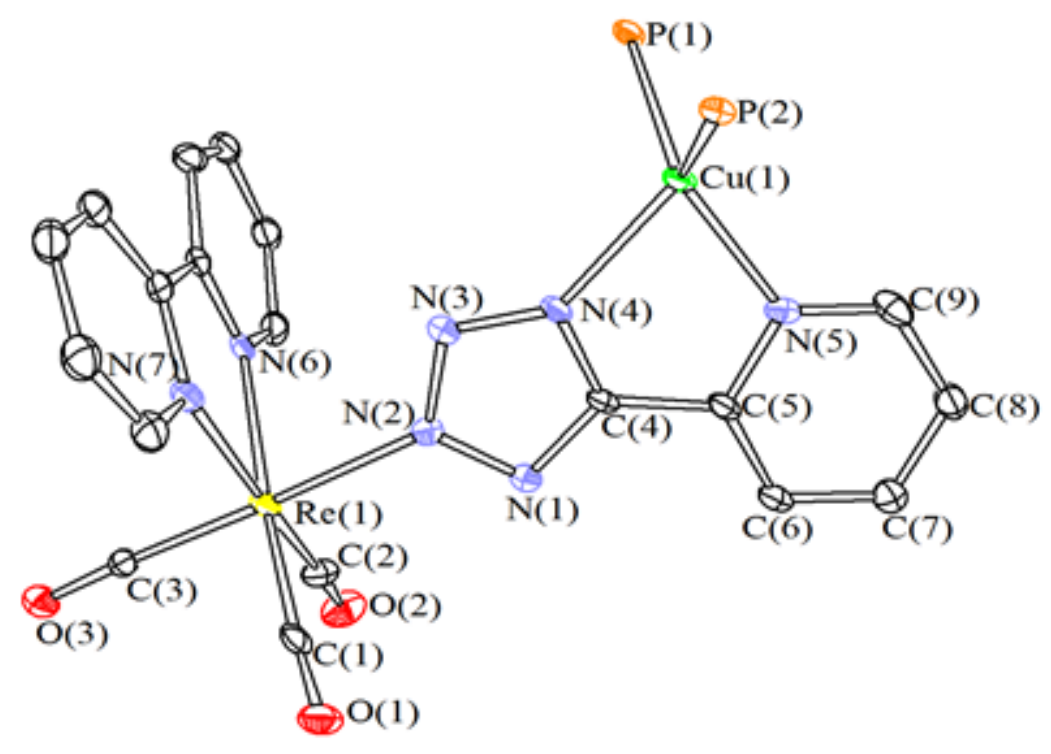

(b)

Figure 4. Molecular structure of [Re-2-PTZ-Cu $]^{+}$with key atoms labelled : (a) full molecule and (b) simplified view (all atoms of POP apart $\mathrm{P}(1)$ and $\mathrm{P}(2)$ have been omitted). Displacement ellipsoids are at the $30 \%$ probability level. Selected bond lengths ( $\AA$ ) and angles (deg): $\operatorname{Re}(1)-\mathrm{C}(1)$ 1.935(9), $\operatorname{Re}(1)-\mathrm{C}(2) 1.896(9), \operatorname{Re}(1)-\mathrm{C}(3)$ 1.903(8), $\operatorname{Re}(1)-\mathrm{N}(2)$ 2.158(7), Re(1)-N(6) 2.168(7), Re(1)-N(7) 2.151(7), N(1)-N(2) 1.346(10), N(2)-N(3) 1.325(9), N(3)-N(4) 1.324(10), $\mathrm{N}(4)-\mathrm{C}(4)$ 1.328(10), N(1)-C(4) 1.337(10), C(4)-C(5) 1.457(12), Cu(1)-N(4) 2.078(7), Cu(1)-N(5) 2.122(7), $\mathrm{Cu}(1)-\mathrm{P}(1)$ 2.255(2), $\mathrm{Cu}(1)-\mathrm{P}(2)$ 2.243(2), N(6)-Re(1)-N(7) 75.4(3), C(1)-Re(1)-N(6) 170.7(3), C(2)-Re(1)-N(7) 170.2(3), C(3)$\operatorname{Re}(1)-\mathrm{N}(2)$ 178.3(3), N(4)-Cu(1)-N(5) 79.6(3), $\mathrm{P}(1)-\mathrm{Cu}(1)-\mathrm{P}(2)$ 109.61(9). 


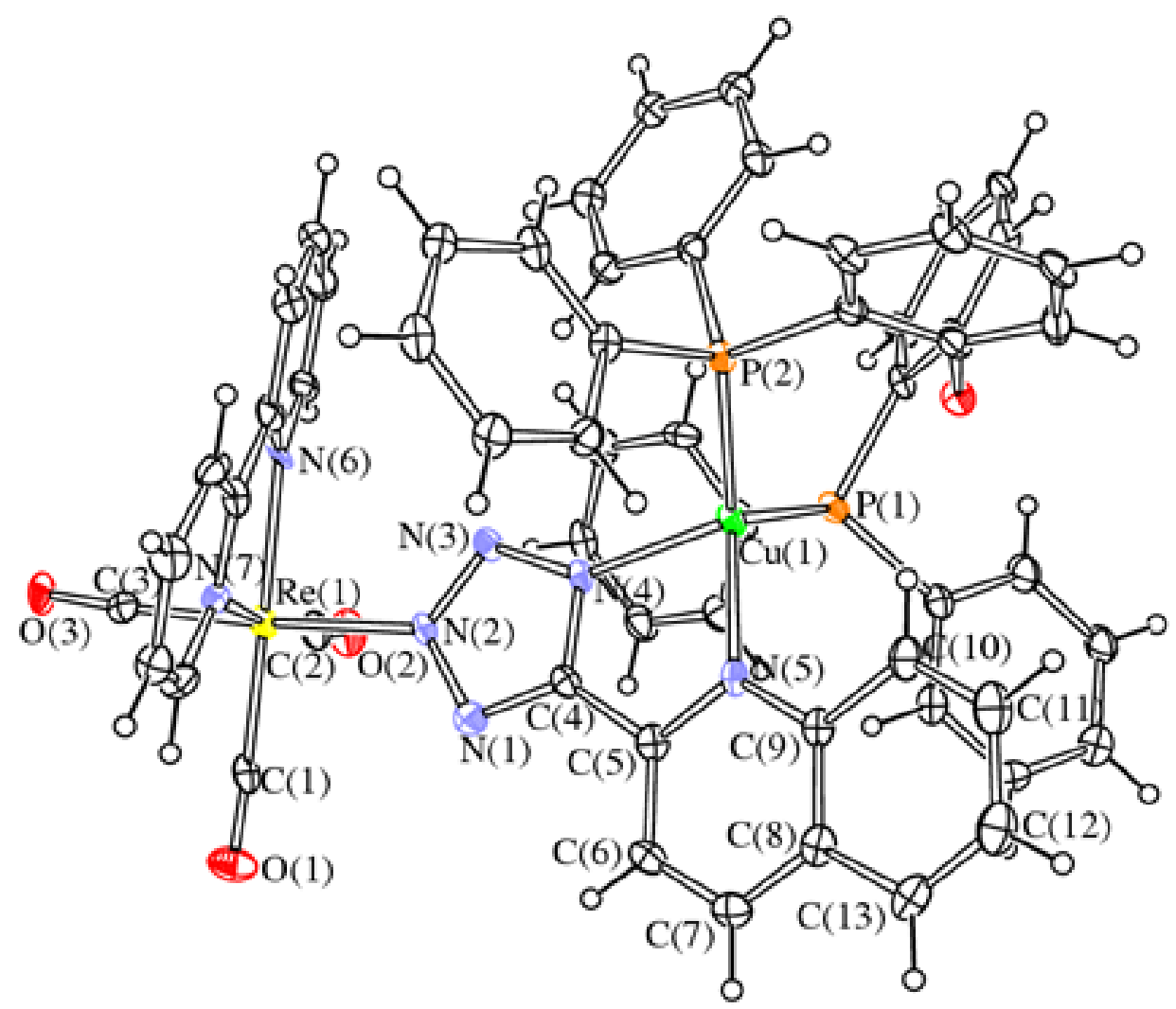

(a)

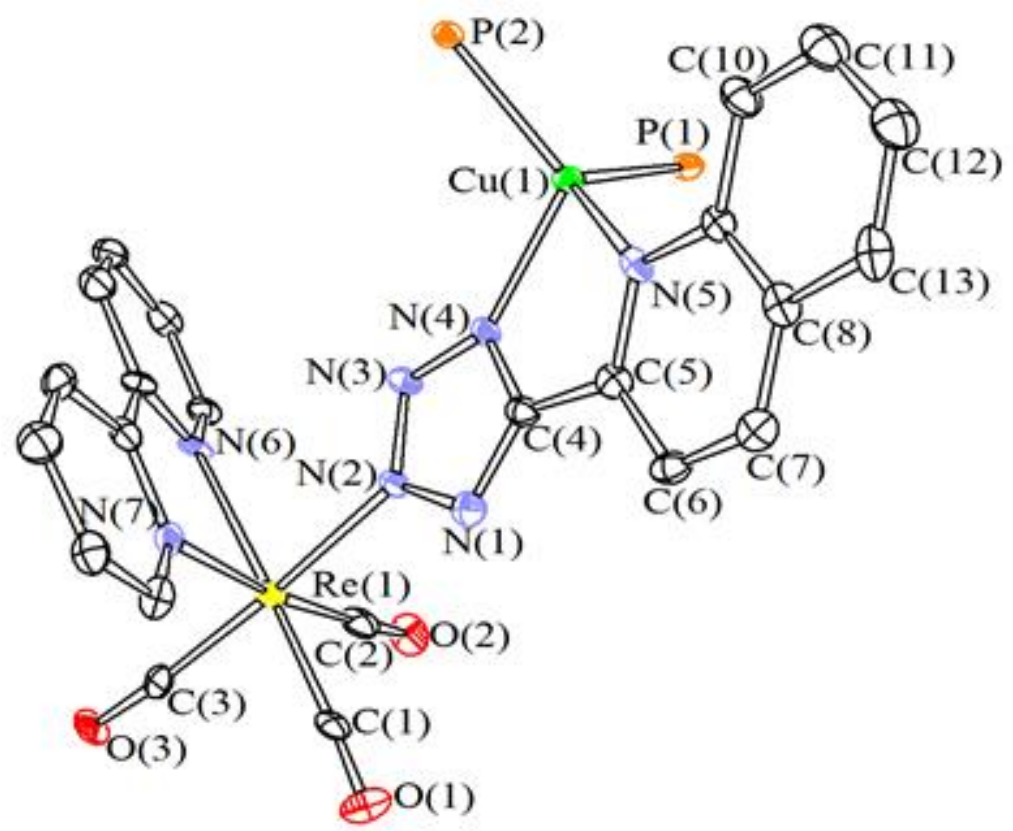

(b)

Figure 5. Molecular structure of [Re-2-QTZ-Cu $]^{+}$with key atoms labelled: (a) full molecule and (b) simplified view (all atoms of POP apart $\mathrm{P}(1)$ and $\mathrm{P}(2)$ have been omitted). Displacement ellipsoids are at the $30 \%$ probability level. Selected bond lengths $(\AA)$ and angles (deg): $\operatorname{Re}(1)-\mathrm{C}(1)$ 1.934(13), $\operatorname{Re}(1)-\mathrm{C}(2) 1.963(14), \operatorname{Re}(1)-\mathrm{C}(3)$ 1.933(12), $\operatorname{Re}(1)-$ $\mathrm{N}(2) \quad 2.167(9), \operatorname{Re}(1)-\mathrm{N}(6) \quad 2.157(9), \operatorname{Re}(1)-\mathrm{N}(7)$ 2.186(10), N(1)-N(2) 1.362(13), N(2)-N(3) 1.326(12), N(3)-N(4) 1.341(12), N(4)-C(4) 1.349(14), N(1)-C(4) 1.317(14), C(4)-C(5) 1.469(15), Cu(1)-N(4) 2.075(9), Cu(1)-N(5) 2.103(9), 
$\mathrm{Cu}(1)-\mathrm{P}(1)$ 2.253(3)， $\mathrm{Cu}(1)-\mathrm{P}(2) \quad 2.230(3) ， \mathrm{~N}(6)-\operatorname{Re}(1)-\mathrm{N}(7)$ 74.5(3)，C(1)-Re(1)-N(6) 170.5(4)，C(2)-Re(1)-N(7) 173.3(4), C(3)-Re(1)-N(2) 176.3(4), N(4)-Cu(1)-N(5) 80.2(4), P(1)-Cu(1)-P(2) 111.26(12). 


\section{Photophysical properties}

Table 1: Summary of photophysical data for the complexes from diluted dichloromethane solutions.

\begin{tabular}{|c|c|c|c|c|c|c|c|c|c|c|}
\hline & Absorption & & & & missic & 298K & & & $\begin{array}{r}\text { Emi } \\
77\end{array}$ & \\
\hline $\begin{array}{l}\text { Complex } \\
\left(\mathrm{CH}_{2} \mathrm{Cl}_{2}\right)\end{array}$ & $\begin{array}{c}\lambda[\mathrm{nm}] \\
\left(10^{-4} \varepsilon\right) \\
{\left[\mathrm{M}^{-1} \mathrm{~cm}^{-1}\right]}\end{array}$ & $\begin{array}{c}\lambda \\
{[\mathrm{nm}]}\end{array}$ & $\begin{array}{c}\tau^{\mathrm{a}} \\
{[\mathrm{ns}]}\end{array}$ & $\begin{array}{c}\tau^{\mathrm{b}} \\
{[\mathrm{ns}]}\end{array}$ & $\begin{array}{c}\varphi^{\mathrm{a}} \\
{[\%]}\end{array}$ & $\begin{array}{c}\varphi^{\mathrm{b}} \\
{[\%]}\end{array}$ & $\begin{array}{c}\mathrm{K}_{\mathrm{r}}^{\mathrm{a}, \mathrm{c}} \\
{\left[10^{5} \mathrm{~s}^{-1}\right]}\end{array}$ & $\begin{array}{c}\mathrm{K}_{\mathrm{nr}}^{\mathrm{a}, \mathrm{c}} \\
{\left[10^{5} \mathrm{~s}^{-1}\right]}\end{array}$ & $\begin{array}{c}\lambda \\
{[\mathrm{nm}]}\end{array}$ & $\begin{array}{c}\tau \\
{[\mu \mathrm{s}]}\end{array}$ \\
\hline$f a c-\left[\operatorname{Re}(\mathbf{p h e n})(\mathrm{CO})_{3}(\mathbf{2}-\mathbf{P T Z})\right]$ & $\begin{array}{l}268(8.23) \\
360(0.96)\end{array}$ & 584 & 308 & 838 & 6.2 & 20.3 & 2.41 & 9.51 & 522 & 7.19 \\
\hline$f a c-\left[\operatorname{Re}(\mathbf{b i p y})(\mathrm{CO})_{3}(\mathbf{2}-\mathbf{P T Z})\right]$ & $\begin{array}{l}280(9.62) \\
338(0.78) \\
422(0.21)\end{array}$ & 596 & 103 & 115 & 1.2 & 7.9 & 6.87 & 80.10 & 528 & 2.84 \\
\hline$f a c-\left[\operatorname{Re}(\mathbf{p h e n})(\mathrm{CO})_{3}(\mathbf{2}-\mathbf{Q T Z})\right]$ & $\begin{array}{l}255(9.54) \\
319(2.30) \\
370(0.76)\end{array}$ & 580 & 342 & 938 & 6.2 & 18.8 & 2.00 & 8.66 & 520 & 6.81 \\
\hline$f a c-\left[\operatorname{Re}(\mathbf{b i p y})(\mathrm{CO})_{3}(\mathbf{2 Q T Z})\right]$ & $\begin{array}{l}244(14.2) \\
318(4.79) \\
370(0.90)\end{array}$ & 598 & 104 & 128 & 3.5 & 5.8 & 4.53 & 73.60 & 536 & 2.90 \\
\hline
\end{tabular}

${ }^{a}$ Measured from an air-equilibrated solution; ${ }^{b}$ Measured from a degassed $\left(\mathrm{O}_{2}\right.$-free $)$ solution,; ${ }^{\mathrm{c}} \mathrm{k}_{r}=(\Phi / \tau), \mathrm{K}_{n r}=(1-\Phi / \tau) ;{ }^{\mathrm{d}}$ in frozen $\mathrm{CH}_{2} \mathrm{Cl}_{2}$ matrix.

The relevant absorption and emission data from diluted $\left(10^{-4} \mathrm{M}\right)$ dichloromethane solutions of all the complexes are listed in Table 1. In general, the absorption and emission features are analogous to previously reported rhenium tetrazolato complexes. In detail, the UV-vis absorption profiles display UV region dominated by intense ligand centred spin allowed $\left({ }^{1} \mathrm{LC}\right)$ absorptions followed, at lower energy, by weaker charge transfer (CT) bands consisting of spin allowed metal to ligand charge transfer $\left({ }^{1}\right.$ MLCT) type transitions (Figure 6 and ESI, figures S11-S12). 


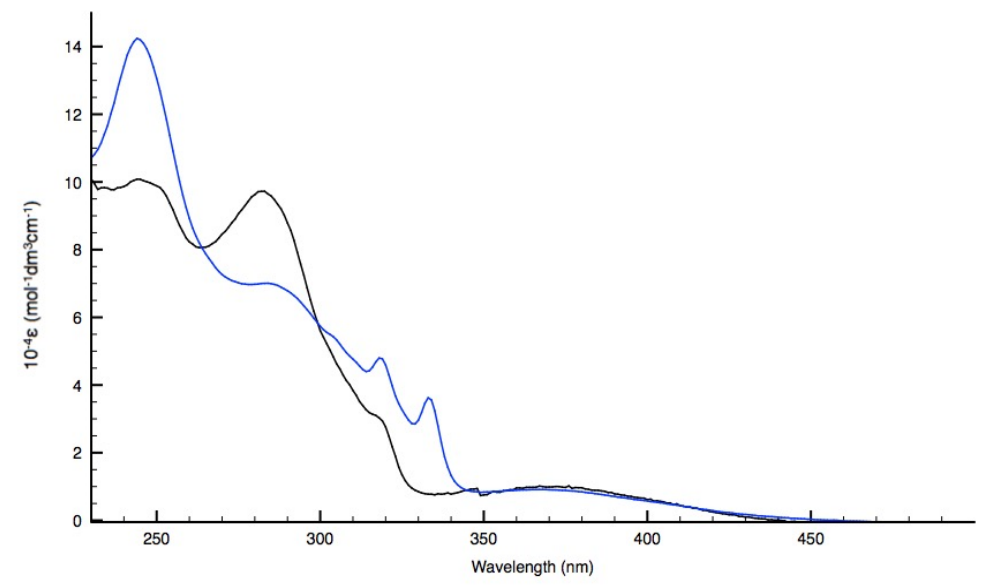

Figure 6. UV-vis absorption profiles of diluted $\left(10^{-4} \mathrm{M}\right)$ dichloromethane solutions $f a c$ - $\left[\operatorname{Re}(\mathbf{b i p y})(\mathrm{CO})_{3}(\mathbf{2}-\mathrm{PTZ})\right]$ (black trace) and $f a c$ - $\left[\operatorname{Re}(\mathbf{b i p y})(\mathrm{CO})_{3}(\mathbf{2}-\mathbf{Q T Z})\right]$ (blue trace).

The complexes display typically broad and structureless emission profiles centered in the 580-600 $\mathrm{nm}$ region at room temperature, with maxima blue-shifted by about $15-20 \mathrm{~nm}$ for the phen-bound complexes (Figure 7 and ESI, figures S13-S16). No significant differences are detected upon exchanging the 2-pyridyl for the 2-quinolyl substituent. In all cases, the excited state lifetime $(\tau)$ and quantum yield $(\Phi)$ are both sensitive to the presence of dissolved $\mathrm{O}_{2}$.

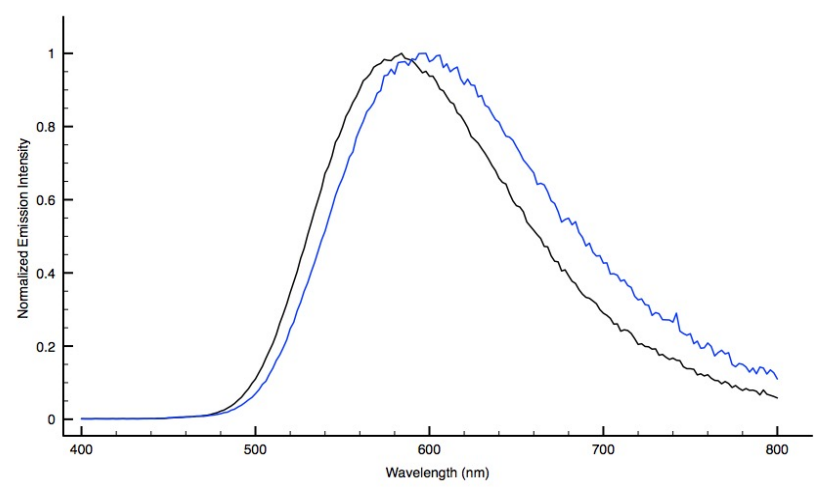

Figure 7: Normalized emission spectra of air equilibrated $\mathrm{CH}_{2} \mathrm{Cl}_{2}$ solutions, of $f a c$ - $\left[\mathrm{Re}(\mathbf{b i p y})(\mathrm{CO})_{3}(\mathbf{2}\right.$-QTZ) $]$ (blue trace) and $f a c-\left[\operatorname{Re}(\mathbf{p h e n})(\mathrm{CO})_{3}(\mathbf{2}-\mathbf{Q T Z})\right]$, (black trace).

Also, at $77 \mathrm{~K}$, the emission profiles appear blue-shifted as a consequence of rigidochromism. Taken together, these data suggest how emission can be here ascribed mainly to phosphorescence from charge transfer states of triplet multiplicity, ${ }^{3} \mathrm{CT}$ (see ESI, figures S13-S16). Further in support to this assignment, a bathochromic shift of the emission bands $\left(\Delta \lambda_{\max }=10-16 \mathrm{~nm}\right)$ is observed on passing from dichloromethane to more polar acetonitrile solutions (see Table 2 for data in $\mathrm{CH}_{3} \mathrm{CN}$ ), enlightening a trend that is commonly encountered when dealing with similar $\operatorname{Re}(\mathrm{I})$ complexes. ${ }^{2 \mathrm{c}, 3 \mathrm{c}}$ 
The luminescence features of the $\mathrm{Re}(\mathrm{I})-\mathrm{Cu}(\mathrm{I})$ bimetallic species $[\mathbf{R e}-(\mathbf{2}-\mathbf{P T Z})-\mathbf{C u}]^{+}$and $[\mathbf{R e}-(\mathbf{2}-$ QTZ)-Cu $]^{+}$appear to be strongly influenced by the presence of the $\mathrm{Cu}(\mathrm{I})$ fragment. At room temperature, the assemblies displayed $\operatorname{Re}(\mathrm{I})$-centered emissions with much lower intensity than those observed under identical experimental conditions for the corresponding mononuclear $\operatorname{Re}(\mathrm{I})$ species (see ESI, table S2 and Figures S17-S21). In addition, and following the behaviour we have reported previously in the case of the $\mathrm{Cu}(\mathrm{I})$ tetrazole-based complex $\left[\left(\mathrm{N}^{\wedge} \mathrm{N}\right) \mathrm{Cu}(\mathrm{POP})\right]^{+},{ }^{11}$ both the heterodinuclear complexes displayed bright luminescence in the solid state at room temperature, with broad and unstructured emission profiles (ESI, figures S20-S21). 


\section{Effects of binding to metal cations}

The neutral tetrazolato complexes were screened with respect to the addition of the divalent metal ions $\mathrm{Zn}(\mathrm{II}), \mathrm{Cd}(\mathrm{II})$ and $\mathrm{Cu}(\mathrm{II})$. In all cases, steady state emission titrations and time-resolved analyses were performed on air equilibrated acetonitrile solutions, to which successive aliquots of the perchlorate salts of the metal ions were added. Upon interaction with $\mathrm{Zn}(\mathrm{II})$ and $\mathrm{Cd}(\mathrm{II})$, a significant increase of the emission intensity and the concomitant blue shift of the emission maxima of the $\operatorname{Re}(\mathrm{I})$ complexes (Table 2, figures 8-9 and ESI, figures S22-S40). These variations occurred at their maximum extent - i.e. the "equivalence point" of the titrations - in correspondence of molar ratios $\mathrm{Re} / \mathrm{Zn}=3 / 1$ and $\mathrm{Re} / \mathrm{Cd}=2 / 1$, respectively.
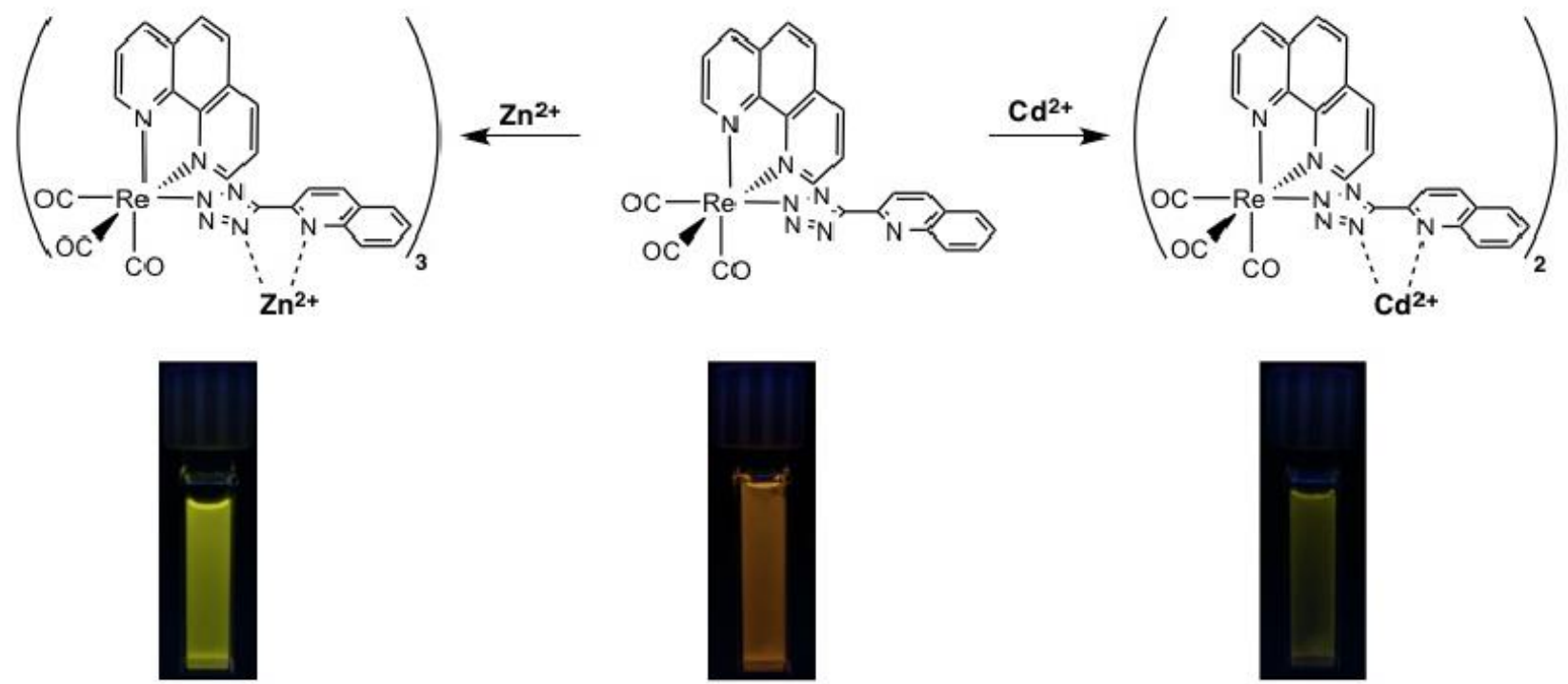

Figure 8. Top: complexation of $f a c-\left[\operatorname{Re}(\mathbf{p h e n})(\mathrm{CO})_{3}(\mathbf{2}-\mathbf{Q T Z})\right]$ with $\mathrm{Zn}$ (II) (left), and $\mathrm{Cd}(\mathrm{II})$ (right). Bottom: images of the cuvettes containing the $\mathrm{CH}_{2} \mathrm{Cl}_{2}$ solutions of $f a c$ - $\left[\mathrm{Re}(\mathbf{p h e n})(\mathrm{CO})_{3}(\mathbf{2}\right.$-QTZ) (middle) and the corresponding adducts with $\mathrm{Zn}(\mathrm{II})$ (left), and Cd(II) (right). $\lambda_{\mathrm{exc}}=365 \mathrm{~nm}$.

From the deeper analysis of the data of steady-state spectra, it could be noticed (see table 2) that the addition of the $\mathrm{Zn}$ (II) ion to the neutral $\mathrm{Re}(\mathrm{I})$ complexes generally induced a blue shift of the emission maximum $\left(\Delta \lambda_{\max }=28-36 \mathrm{~nm}\right)$ that is very similar to the one detected following their interaction with $\mathrm{Cd}(\mathrm{II})\left(\Delta \lambda_{\max }=22-30 \mathrm{~nm}\right)$. For both the divalent ions, the amplification factors of the $\operatorname{Re}(\mathrm{I})$-based emission intensities (I/Io, see table 2) were found to span between 1.4 and 2.6, enlightening a trend that appeared essentially governed by the presence of phen or bipy ancillary ligands in the structure of the $\operatorname{Re}(\mathrm{I})$ complexes, respectively. 

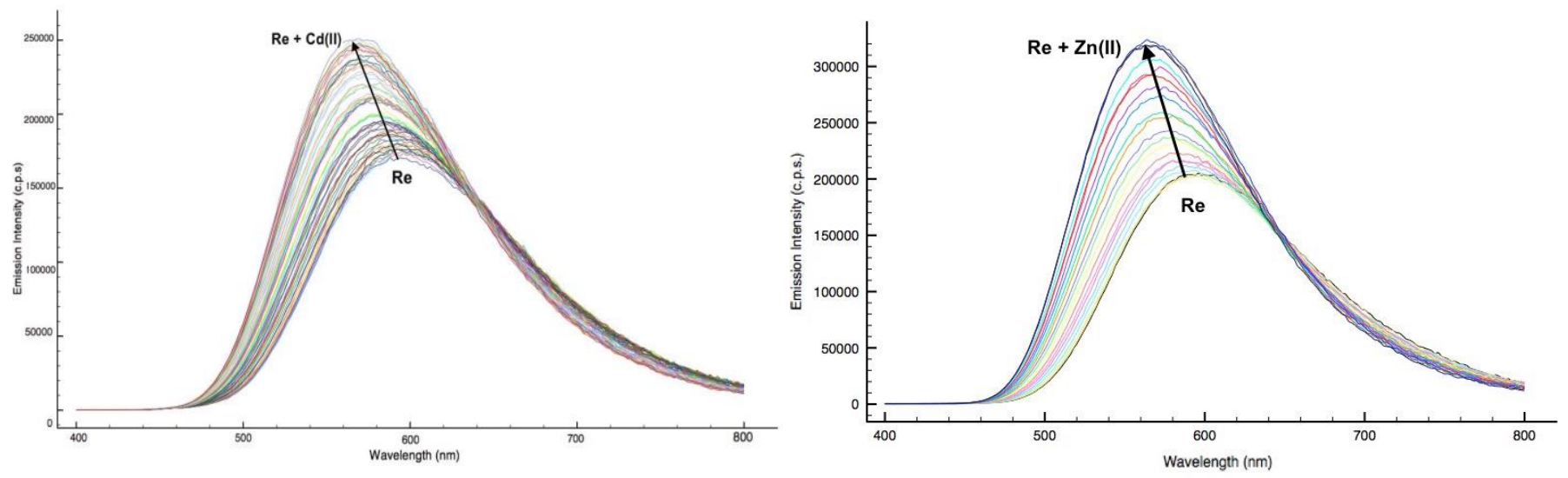

Figure 9. Steady-state emission spectra showing the blue shift and the increase of emission intensity of fac$\left[\operatorname{Re}(\right.$ phen $\left.)(\mathrm{CO})_{3}(\mathbf{2}-\mathbf{Q T Z})\right]\left(1,55^{*} 10^{-4} \mathrm{M}\right.$ in $\left.\mathrm{CH}_{3} \mathrm{CN}\right)$, denoted as "Re", upon successive additions of $10 \mu \mathrm{L}$ aliquots of $\left[\mathrm{Cd}\left(\mathrm{ClO}_{4}\right)_{2}\right]\left(2,38 * 10^{-4} \mathrm{M}\right.$ in $\left.\mathrm{CH}_{3} \mathrm{CN}\right)-$ left - and $\left[\mathrm{Zn}\left(\mathrm{ClO}_{4}\right)_{2}\right]\left(5,37 * 10^{-4}\right.$ in $\left.\mathrm{CH}_{3} \mathrm{CN}\right)-$ right.

With regard to the time-resolved measurements, it is worth noting how the further complexation of all the neutral $\operatorname{Re}(\mathrm{I})$ species with $\mathrm{Zn}(\mathrm{II})$ or $\mathrm{Cd}(\mathrm{II})$ did result in the $c a$. 1.5 to 2.5 -fold elongation of the emission lifetimes $(\tau)$ (Figure 10 and ESI, figures S32, S36 and S40).

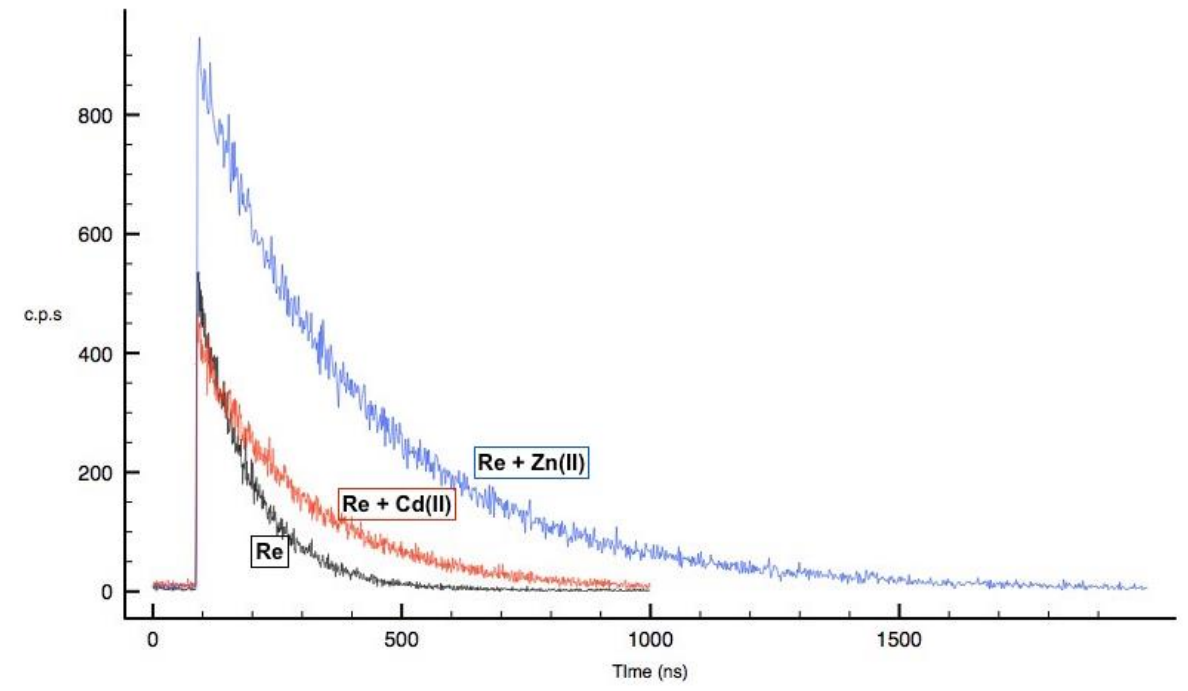

Figure 10. Comparison of lifetime decays of $f a c-\left[\operatorname{Re}(\mathbf{p h e n})(\mathrm{CO})_{3}(\mathbf{2}-\mathbf{Q} \mathbf{Q T Z})\right]$ denoted as "Re", in the absence (black trace) and in the presence of $\mathrm{Cd}(\mathrm{II})$ (red trace) and $\mathrm{Zn}(\mathrm{II})$ (blue trace).

Overall, such an improved performance is in agreement with the energy gap law ${ }^{15}$ and, even if occurring to an extent slightly lower than what was observed for the protonation and for the methylation of similar $\operatorname{Re}(\mathrm{I})$ tetrazolato substrates $\left(\Delta \lambda_{\max }=48 \mathrm{~nm}\right),{ }^{5}$ provides a further evidence of the effective reduction of the contribution coming from the tetrazolato ligand in the composition of the emissive excited states, which therefore become mostly ${ }^{3} \mathrm{MLCT}(\mathrm{Re} \rightarrow \mathbf{d i i m})$ in nature. 
However, the nature of the targeted metal ion played a fundamental role in determining the luminescence response of the complexes. Indeed, at contrast to what observed for the interaction of $\mathrm{Zn}(\mathrm{II})$ or $\mathrm{Cd}(\mathrm{II})$ with the $\mathrm{Re}(\mathrm{I})$ tetrazolato complexes, the addition of the $\mathrm{Cu}(\mathrm{II})$ ion caused the progressive suppression of the $\operatorname{Re}(\mathrm{I})$ based phosphorescence (Table 2, figure 11, and figures $\mathrm{S} 31$, S35, and S39). The occurrence of such a "turn-off" effect might be confidently explained in consideration of the wellknown ability of $\mathrm{Cu}(\mathrm{II})$ ions to quench emissive excited states, ${ }^{16}$ including the intervention of $\operatorname{Re}(\mathrm{I})-\mathrm{Cu}$ (II) energy transfer which is likely to be among the factors that govern the quenching mechanisms. The quenching of emission has been investigated by Stern-Volmer analysis and the obtained trend (see ESI, figure S44 and table S3) suggests how this process may be eventually described as the combination of both static and dynamic quenching.

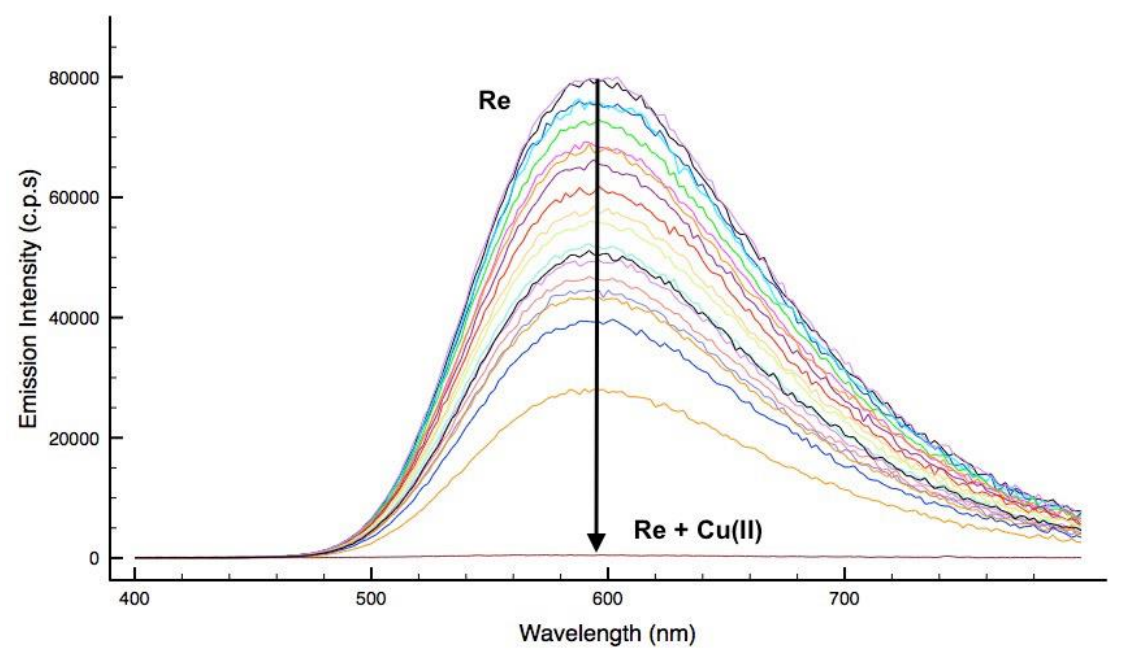

Figure 11. Steady-state emission spectra showing the suppression of radiative processes of $f a c-\left[\operatorname{Re}(\mathbf{p h e n})(\mathrm{CO})_{3}(\mathbf{2}-\right.$ QTZ)] $\left(1,55^{*} 10^{-4} \mathrm{M}\right.$ in $\left.\mathrm{CH}_{3} \mathrm{CN}\right)$, denoted as "Re", upon successive additions of $5 \mu \mathrm{L}$ aliquots of $\left[\mathrm{Cu}\left(\mathrm{ClO}_{4}\right)_{2}\right]\left(2,69^{*} 10^{-}\right.$ ${ }^{4} \mathrm{M}$ in $\left.\mathrm{CH}_{3} \mathrm{CN}\right)$. 
Table 2. Summary of the photophysical data of the $\mathrm{Re}(\mathrm{I})$ complexes in $\mathrm{CH}_{3} \mathrm{CN}$ before and after the addition of the $\mathrm{CH}_{3} \mathrm{CN}$ solutions of the divalent metal ions.

\begin{tabular}{|c|c|c|c|c|c|}
\hline & Absorption & & Emis & $298 K^{2}$ & \\
\hline $\begin{array}{l}\text { Complex } \\
\left(\mathrm{CH}_{3} \mathrm{CN}\right)\end{array}$ & $\begin{array}{c}\lambda[\mathrm{nm}] \\
\left(10^{-4} \varepsilon\right)\left[\mathrm{M}^{-1} \mathrm{~cm}^{-1}\right]\end{array}$ & $\begin{array}{c}\lambda \\
{[\mathrm{nm}]}\end{array}$ & $\begin{array}{c}\tau \\
{[\mathrm{ns}]}\end{array}$ & $\begin{array}{c}\Delta \lambda \\
{[\mathrm{nm}]^{\mathrm{b}}}\end{array}$ & $I / I_{0}^{c}$ \\
\hline$f a c-\left[\operatorname{Re}(\right.$ phen $\left.)(\mathrm{CO})_{3}(\mathbf{2}-\mathbf{Q T Z})\right]$ & $\begin{array}{c}243(18.38), 274(12.85), 318 \\
(5.22), 332(5.52)\end{array}$ & 594 & 107 & 0 & 1 \\
\hline$f a c-\left[\operatorname{Re}(\right.$ phen $\left.)(\mathrm{CO})_{3}(\mathbf{2}-\mathbf{Q T Z})\right]+\mathbf{Z n}^{2+}$ & $\begin{array}{c}249 \text { (16.49), } 275(9.03), 323 \\
(4.14), 335(3.81)\end{array}$ & 564 & 324 & 30 & 1.55 \\
\hline$f a c-\left[\operatorname{Re}(\right.$ phen $\left.)(\mathrm{CO})_{3}(\mathbf{2}-\mathbf{Q T Z})\right]+\boldsymbol{C d}^{2+}$ & $\begin{array}{c}249 \text { (19.89), } 274(11.64), 323 \\
(5.28), 336(4.70)\end{array}$ & 570 & 219 & 24 & 1.41 \\
\hline$f a c-\left[\operatorname{Re}(\right.$ phen $\left.)(\mathrm{CO})_{3}(\mathbf{2}-\mathbf{Q T Z})\right]+\boldsymbol{C} \boldsymbol{u}^{2+}$ & $\begin{array}{c}253(22.66), 275(12.62), 330 \\
(5.73), 341(5.36)\end{array}$ & 594 & n.d & 0 & $>0.01$ \\
\hline$f a c-\left[\operatorname{Re}(\mathbf{b i p y})(\mathrm{CO})_{3}(\mathbf{2 - Q T Z})\right]$ & $\begin{array}{c}243(7.13), 317(2.92), 332 \\
(2.13)\end{array}$ & 608 & 104 & 0 & 1 \\
\hline$f a c-\left[\operatorname{Re}(\mathbf{b i p y})(\mathrm{CO})_{3}(\mathbf{2}-\mathbf{Q T Z})\right]+\mathbf{Z n}^{2+}$ & $\begin{array}{c}250(11.17), 319(3.88), 336 \\
(2.53)\end{array}$ & 572 & 270 & 36 & 2.38 \\
\hline$f a c-\left[\operatorname{Re}(\mathbf{b i p y})(\mathrm{CO})_{3}(\mathbf{2}-\mathbf{Q T Z})\right]+\boldsymbol{C} \boldsymbol{d}^{2+}$ & $\begin{array}{c}248(7.50), 319(2.78), 337 \\
(1.76)\end{array}$ & 578 & 135 & 30 & 2.63 \\
\hline$f a c-\left[\operatorname{Re}(\mathbf{b i p y})(\mathrm{CO})_{3}(\mathbf{2}-\mathbf{Q T Z})\right]+\boldsymbol{C u}^{2+}$ & $\begin{array}{c}246(15.49), 276(14.24), 330 \\
(3.07)\end{array}$ & 608 & n.d. & n.d. & 0.02 \\
\hline$f a c-\left[\operatorname{Re}(\right.$ phen $\left.)(\mathrm{CO})_{3}(\mathbf{2}-\mathbf{P T Z})\right]$ & $\begin{array}{c}262(9.21), 269(9.39), 276 \\
(8.81), 349(1.11)\end{array}$ & 598 & 108 & 0 & 1 \\
\hline$f a c-\left[\operatorname{Re}(\right.$ phen $\left.)(\mathrm{CO})_{3}(\mathbf{2}-\mathbf{P T Z})\right]+Z^{2+}$ & $\begin{array}{c}262(7.38), 269(7.93), 276 \\
(7.99), 350(0.90)\end{array}$ & 570 & 175 & 28 & 1.96 \\
\hline$f a c-\left[\operatorname{Re}(\right.$ phen $\left.)(\mathrm{CO})_{3}(\mathbf{2}-\mathrm{PTZ})\right]+\boldsymbol{C} \boldsymbol{d}^{2+}$ & $\begin{array}{c}262(8.03), 269(8.64), 276 \\
(8.81), 353(0.96)\end{array}$ & 576 & 135 & 22 & 1.42 \\
\hline$f a c-\left[\operatorname{Re}(\right.$ phen $\left.)(\mathrm{CO})_{3}(\mathbf{2}-\mathbf{P T Z})\right]+\boldsymbol{C} \boldsymbol{u}^{2+}$ & $\begin{array}{c}272(6.68), 297(3.75), 360 \\
(0.68)\end{array}$ & 584 & n.d & 14 & 0.04 \\
\hline$f a c-\left[\operatorname{Re}(\mathbf{b i p y})(\mathrm{CO})_{3}(\mathbf{2}-\mathbf{P T Z})\right]$ & $\begin{array}{c}280(4.22), 308(2.95), 318 \\
\quad(2.79), 356(0.56)\end{array}$ & 612 & 44 & 0 & 1 \\
\hline$f a c-\left[\operatorname{Re}(\mathbf{b i p y})(\mathrm{CO})_{3}(\mathbf{2}-\mathbf{P T Z})\right]+Z \mathbf{n}^{2+}$ & $\begin{array}{c}280(7.18), 308(4.01), 318 \\
(3.89), 356(0.81)\end{array}$ & 582 & 99 & 30 & 2.38 \\
\hline$f a c-\left[\operatorname{Re}(\mathbf{b i p y})(\mathrm{CO})_{3}(\mathbf{2}-\mathbf{P T Z})\right]+\boldsymbol{C} \boldsymbol{d}^{2+}$ & $\begin{array}{c}280(6.58), 308(6.37), 318 \\
(6.61), 356(1.89)\end{array}$ & 582 & 97 & 30 & 2.23 \\
\hline$f a c-\left[\operatorname{Re}(\mathbf{b i p y})(\mathrm{CO})_{3}(\mathbf{2}-\mathbf{P T Z})\right]+\boldsymbol{C} \boldsymbol{u}^{2+}$ & $\begin{array}{c}241(10.58), 285(7.30), 318 \\
(5.10), 342(1.43)\end{array}$ & 592 & n.d & 0 & 0.03 \\
\hline
\end{tabular}

\footnotetext{
${ }^{\mathrm{a}}$ Measured from air-equilibrated solutions; ${ }^{\mathrm{b}} \Delta \lambda(\mathrm{nm})=\left[\left(\lambda_{\max }\right.\right.$ complex $\left.+\mathrm{M}^{2+}\right)-\left(\lambda_{\max }\right.$ complex $\left.)\right] ;{ }^{\mathrm{b}}: \mathrm{I} / \mathrm{I}_{0}=$ Emission intensity at $\lambda_{\max }$ of the complex $+\mathrm{M}^{2+}(\mathrm{I})$, over emission intensity at $\lambda_{\max }$ of the free complex $\left(\mathrm{I}_{0}\right)$.
} 


\section{Conclusions}

Taking advantage of the possibility of varying the emission features of luminescent metal tetrazolato complexes upon the addition of electrophiles to the coordinated tetrazolato ring, we endeavored to design $\operatorname{Re}(\mathrm{I})$ tetrazolato complexes capable of providing a further and specific diimine-type coordinative interaction with some selected divalent metal cations. We pursued this goal by introducing either 2-pyridyl tetrazolato or 2-quinolyl tetrazolato as anionic ancillary ligands to the $\operatorname{Re}(\mathrm{I})$ complexes. These four new compounds displayed orange to red colored emission originating from ${ }^{3} \mathrm{CT}$ excited states. At first, the chelating ability of the ancillary ligands toward further metal ions was verified with the preparation of discrete $\operatorname{Re}(\mathrm{I})-\mathrm{Cu}(\mathrm{I})$ dyads. Equally important information was deduced from the observation of how the coordination of the $\mathrm{Cu}(\mathrm{I})$ moiety through the $\operatorname{Re}(\mathrm{I})$-appended $\mathbf{2 - P T Z}$ or $\mathbf{2}-\mathbf{Q T Z}^{-}$ligand did involve the substantial variation of the luminescent features of the "free" $\operatorname{Re}(\mathrm{I})$ mononuclear derivatives. The sensing abilities of the new $\operatorname{Re}(\mathrm{I})$ complexes were investigated with respect to their interaction with divalent metal cations of biological and toxicological importance, such as $\mathrm{Zn}(\mathrm{II}), \mathrm{Cd}(\mathrm{II})$ and $\mathrm{Cu}(\mathrm{II})$. By performing emission titrations, we investigated how the local perturbation of the tetrazolato ligands that was caused by their complexation with the $\mathrm{Zn}$ (II) or the $\mathrm{Cd}(\mathrm{II})$ ion determined a blue shift of the emission profiles of the $\operatorname{Re}(\mathrm{I})$ complexes, which also displayed an appreciable increase of the phosphorescence intensities and elongated emission lifetimes. It is important to note that the intrinsic nature of the added divalent ions also played a key role in determining the variation of the emission properties of the $\operatorname{Re}(\mathrm{I})$-tetrazolato complexes described herein. Indeed, an exactly opposite trend - i.e. the "turn off" of the luminescence of the Re(I) complexes - was detected upon the addition of a common quencher of emissive excited states such the $\mathrm{Cu}$ (II) ion. The occurrence of such antithetic effects might suggest the potential of these new $\operatorname{Re}(\mathrm{I})$ tetrazolato complexes as prototypal discriminatory probes. To this extent, and to widen the applicative scenario of these new $\operatorname{Re}(\mathrm{I})$ species, the investigation of their biological behaviour with respect to live substrates such as Yarrowia lypolitica yeast cells is currently underway. 


\section{EXPERIMENTAL SECTION}

General considerations. All the reagents and solvents were obtained commercially (e.g. Aldrich) and used as received without any further purification, unless otherwise specified. $\left[\mathrm{Cu}\left(\mathrm{CH}_{3} \mathrm{CN}\right)_{4}\right]\left[\mathrm{BF}_{4}\right]$ was prepared according to a published procedure. ${ }^{17}$ All the reactions were carried out under an argon atmosphere following Schlenk protocols. Where required, the purification of the Re complexes was performed via column chromatography with the use of neutral alumina as the stationary phase. ESI-mass spectra were recorded using a Waters ZQ-4000 instrument (ESI-MS, acetonitrile as the solvent). IR spectra were recorded as dichloromethane (DCM) solutions, using a $\mathrm{NaCl}(5 \mathrm{~mm})$ disc on a PerkinElmer Spectrum 2000 FT-IR spectrometer. Nuclear magnetic resonance spectra (consisting of ${ }^{1} \mathrm{H}$, and ${ }^{13} \mathrm{C}$ experiments) were always recorded using a Varian Mercury Plus 400 instrument $\left({ }^{1} \mathrm{H}, 400.1\right.$; ${ }^{13} \mathrm{C}, 101.0 \mathrm{MHz}$ ) at room temperature. ${ }^{1} \mathrm{H}$ and ${ }^{13} \mathrm{C}$ chemical shifts were referenced to residual solvent resonances.

Photophysics. Absorption spectra were recorded at room temperature using a Perkin Elmer Lambda 35 UV/vis spectrometer. Uncorrected steady-state emission and excitation spectra were recorded on an Edinburgh FLSP920 spectrometer equipped with a $450 \mathrm{~W}$ xenon arc lamp, double excitation and single emission monochromators, and a Peltier-cooled Hamamatsu R928P photomultiplier tube (185-850 nm). Emission and excitation spectra were corrected for source intensity (lamp and grating) and emission spectral response (detector and grating) by a calibration curve supplied with the instrument. The wavelengths for the emission and excitation spectra were determined using the absorption maxima of the MLCT transition bands (emission spectra) and at the maxima of the emission bands (excitation spectra). Quantum yields $(\Phi)$ were determined using the optically dilute method by Crosby and Demas ${ }^{18}$ at excitation wavelength obtained from absorption spectra on a wavelength scale $[\mathrm{nm}]$ and compared to the reference emitter by the following equation: ${ }^{19}$

$$
\phi_{s}=\phi_{r}\left[\frac{A_{r}\left(\lambda_{r}\right)}{A_{s}\left(\lambda_{s}\right)}\right]\left[\frac{I_{r}\left(\lambda_{r}\right)}{I_{s}\left(\lambda_{s}\right)}\right]\left[\frac{n_{s}^{2}}{n_{r}^{2}}\right]\left[\frac{D_{s}}{D_{r}}\right]
$$

where $\mathrm{A}$ is the absorbance at the excitation wavelength $(\lambda)$, I is the intensity of the excitation light at the excitation wavelength $(\lambda), \mathrm{n}$ is the refractive index of the solvent, $\mathrm{D}$ is the integrated intensity of the luminescence, and $\Phi$ is the quantum yield. The subscripts $r$ and $s$ refer to the reference and the sample, respectively. A stock solution with an absorbance $>0.1$ was prepared, then two dilutions were obtained with dilution factors of 20 and 10, resulting in absorbances of about 0.02 and 0.08 respectively. The Lambert-Beer law was assumed to remain linear at the concentrations of the solutions. The degassed measurements were obtained after the solutions were bubbled for 10 minutes under Ar atmosphere, using a septa-sealed quartz cell. Air-equilibrated $\left[\mathrm{Ru}(\mathrm{bpy})_{3}\right] \mathrm{Cl}_{2} / \mathrm{H}_{2} \mathrm{O}$ solution $(\Phi=0.028)^{20}$ was used as reference. The quantum yield 
determinations were performed at identical excitation wavelengths for the sample and the reference, therefore deleting the $\mathrm{I}\left(\lambda_{\mathrm{r}}\right) / \mathrm{I}\left(\lambda_{\mathrm{S}}\right)$ term in the equation. Emission lifetimes $(\tau)$ were determined with the single photon counting technique (TCSPC) with the same Edinburgh FLSP920 spectrometer using pulsed picosecond LED (EPLED 360, fhwm $<800 \mathrm{ps}$ ) as the excitation source, with repetition rates between $1 \mathrm{kHz}$ and $1 \mathrm{MHz}$, and the above-mentioned R928P PMT as detector. The goodness of fit was assessed by

minimizing the reduced $\chi^{2}$ function and by visual inspection of the weighted residuals. To record the $77 \mathrm{~K}$ luminescence spectra, the samples were put in quartz tubes ( $2 \mathrm{~mm}$ diameter) and inserted in a special quartz dewar filled with liquid nitrogen. The solvent used in the preparation of the solutions for the photophysical investigations was of spectrometric grade. Experimental uncertainties are estimated to be $\pm 8 \%$ for lifetime determinations, $\pm 20 \%$ for quantum yields, and $\pm 2 \mathrm{~nm}$ and $\pm 5 \mathrm{~nm}$ for absorption and emission peaks, respectively.

\section{Ligand synthesis}

Warning! Tetrazole derivatives are used as components for explosive mixtures. ${ }^{21}$ In this lab, the reactions described here were only run on a few grams scale and no problems were encountered. However, great caution should be exercised when handling or heating compounds of this type.

Following the general method reported by Koguro and coworkers, ${ }^{8 b} 2-(1 H$-tetrazol-5-yl)quinoline (2-QTZH) was obtained in almost quatitative yield $(0.769 \mathrm{~g}, 99 \%),{ }^{1} \mathrm{H}-\mathrm{NMR}, 400 \mathrm{MHz}, \mathrm{DMSO}-d^{6} \delta(\mathrm{ppm})=8.65(\mathrm{~d}$, $\left.1 \mathrm{H}, J_{\mathrm{H}-\mathrm{H}}=8.79 \mathrm{~Hz}\right), 8.31\left(\mathrm{~d}, 1 \mathrm{H}, J_{\mathrm{H}-\mathrm{H}}=8.40 \mathrm{~Hz}\right), 8.17\left(\mathrm{~d}, 1 \mathrm{H}, J_{\mathrm{H}-\mathrm{H}}=8.40 \mathrm{~Hz}\right), 8.12\left(\mathrm{~d}, 1 \mathrm{H}, J_{\mathrm{H}-\mathrm{H}}=7.99 \mathrm{~Hz}\right)$, $7.90(\mathrm{t}, 1 \mathrm{H}), 7.74(\mathrm{t}, 1 \mathrm{H})$.

In a slightly different approach, ${ }^{8 \mathrm{a}}$ 2-(1H-tetrazol-5yl) pyridine (2-PTZH) was obtained in good yield (: 1.020 g, 72\%) by reaction of pyridine-2-carbonitrile with $\mathrm{NaN}_{3}$, in the presence of $\mathrm{NH}_{4} \mathrm{Cl}$ and $\mathrm{LiCl}$, in $\mathrm{DMF}$ as solvent. ${ }^{1} \mathrm{H}-\mathrm{NMR}, 400 \mathrm{MHz}, \mathrm{DMSO}-d^{6} \delta(\mathrm{ppm})=8.77\left(\mathrm{~d}, 1 \mathrm{H}, J_{\mathrm{H}-\mathrm{H}}=5.6 \mathrm{~Hz}\right), 8.20\left(\mathrm{~d}, 1 \mathrm{H}, J_{\mathrm{H}-\mathrm{H}}=8 \mathrm{~Hz}\right)$, 8.07-8.03 (m, 1H), 7.62-7.59 (m, 1H). ${ }^{13} \mathrm{C}-\mathrm{NMR}, 100 \mathrm{MHz}, \mathrm{DMSO}-d^{6} \delta(\mathrm{ppm})=155.3(\mathrm{Ct}), 150.5,144.1$, $138.7,126.6,123.1$.

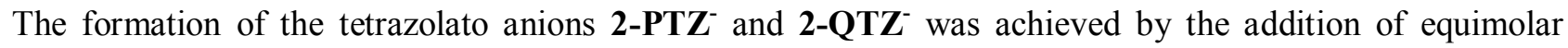
amounts of triethylamine to a suspension of the neutral 5 -substituted tetrazoles in $5.0 \mathrm{~mL}$ of an ethanol/water $(3: 1 \mathrm{v} / \mathrm{v})$ at room temperature. The resulting pale-yellow solutions were used without any further purification.

\section{General Procedure for the Preparation of the Neutral $f a c-\left[\operatorname{Re}\left(\mathrm{N}^{\wedge} \mathrm{N}\right)(\mathrm{CO})_{3} \mathrm{~L}\right]-\mathrm{Type}$ Complexes}

A $0.100 \mathrm{~g}$ aliquot of $f a c-\left[\operatorname{Re}\left(\mathrm{N}^{\wedge} \mathrm{N}\right)(\mathrm{CO})_{3} \mathrm{Br}\right]\left(0.22 \mathrm{mmol}\right.$ for $\mathrm{N}^{\wedge} \mathrm{N}=$ bipy; $0.13 \mathrm{mmol}$ if $\mathrm{N}^{\wedge} \mathrm{N}=$ phen $)$ was dissolved in $20 \mathrm{~mL}$ of an ethanol/water mixture $(3: 1 \mathrm{v} / \mathrm{v})$ under an $\mathrm{Ar}$ atmosphere. A $5.0 \mathrm{~mL}$ portion of an ethanol/water $(3: 1 \mathrm{v} / \mathrm{v})$ solution containing 1.5 molar equivalents (calculated with respect to the starting fac$\left.\left[\operatorname{Re}\left(\mathrm{N}^{\wedge} \mathrm{N}\right)(\mathrm{CO})_{3} \mathrm{Br}\right]\right)$ of the appropriate tetrazolato salt was added dropwise. Once the addition was 
completed, the resulting suspension was stirred at the reflux temperature for $24 \mathrm{~h}$. After this time, the mixture was cooled to r.t. and filtered through a glass frit, affording the desired complexes as a yellow microcrystalline powder. The product complexes did not require any further purification process.

fac-[Re(phen)(CO) 3 (2-QTZ)]: 0.102 g, 84\%. ESI-MS $(m / z)=647[\mathrm{M}+\mathrm{H}]^{+} .{ }^{1} \mathrm{H}-\mathrm{NMR} 400 \mathrm{MHz}$, Acetone- $d^{6}$ $\delta(\mathrm{ppm})=9.74\left(\mathrm{~d}, 2 \mathrm{H}, J_{\mathrm{H}-\mathrm{H}}=6.40 \mathrm{~Hz}\right), 9.01\left(\mathrm{~d}, 2 \mathrm{H}, J_{\mathrm{H}-\mathrm{H}}=9.60 \mathrm{~Hz}\right), 8.34(\mathrm{~s}, 2 \mathrm{H}), 8.23(\mathrm{~m}, 3 \mathrm{H}), 7.99(\mathrm{~d}, 1 \mathrm{H}$, $\left.J_{\mathrm{H}-\mathrm{H}}=8.79 \mathrm{~Hz}\right), 7.87(\mathrm{~m}, 2 \mathrm{H}), 7.72(\mathrm{~m}, 1 \mathrm{H}), 7.55(\mathrm{~m}, 1 \mathrm{H}) \cdot{ }^{13} \mathrm{C}-\mathrm{NMR} 100 \mathrm{MHz}$, Acetone- $d^{6} \delta(\mathrm{ppm})=$ 197.31 (CO), 195.40 (CO), 189.9 (CO), 163.55 (Ct), 154.87 (C $\mathrm{C}_{\text {ipso }}$ ), 148.93, 147.76, 146.90, 140,29, 137.22, $130.79,130.35,129.41,128.29,128.23,127.74,127.24,127.15,120.15$. Crystals suitable for X-ray analysis (identified as $f a c$ - $\left[\mathrm{Re}(\mathrm{phen})(\mathrm{CO})_{3}(2-\mathrm{QTZ})\right] \cdot 0.5 \mathrm{CH}_{2} \mathrm{Cl}_{2}, \mathrm{C}_{25.5} \mathrm{H}_{15} \mathrm{~N}_{7} \mathrm{ClO}_{3} \mathrm{Re}$ ) were obtained by slow diffusion of diethyl ether into a solution of the complex in dichloromethane. Anal. Calcd. for $\mathrm{C}_{25.5} \mathrm{H}_{15} \mathrm{~N}_{7} \mathrm{ClO}_{3} \mathrm{Re}$ (689.10): C 44.44, H 2.19, N 14.23. Found: C 44.48, H 2.25, N 14.28\%.

$f a c-\left[\operatorname{Re}(\right.$ bipy $\left.)(\mathrm{CO})_{3}(\mathbf{2}-\mathbf{Q T Z})\right]: 0.076 \mathrm{~g}, 62 \%$. ESI-MS $(\mathrm{m} / \mathrm{z})=624[\mathrm{M}+\mathrm{H}]^{+} .{ }^{1} \mathrm{H}-\mathrm{NMR} 400 \mathrm{MHz}$, Acetone- $d^{6}$ $\delta(\mathrm{ppm})=9.29(\mathrm{~m}, 2 \mathrm{H}), 8.70\left(\mathrm{~d}, 2 \mathrm{H}, J_{\mathrm{H}-\mathrm{H}}=7.99 \mathrm{~Hz}\right), 8.37(\mathrm{~m}, 2 \mathrm{H}), 8.24\left(\mathrm{~d}, 1 \mathrm{H}, J_{\mathrm{H}-\mathrm{H}}=8.79 \mathrm{~Hz}\right), 7.98(\mathrm{~m}$, $2 \mathrm{H}), 7.88\left(\mathrm{~d}, 1 \mathrm{H}, J_{\mathrm{H}-\mathrm{H}}=8.39 \mathrm{~Hz}\right), 7.85(\mathrm{~m}, 2 \mathrm{H}), 7.13(\mathrm{~m}, 1 \mathrm{H}), 7.53(\mathrm{~m}, 1 \mathrm{H}) .{ }^{13} \mathrm{C}-\mathrm{NMR} 100 \mathrm{MHz}, \mathrm{DMSO}-d^{6}$ $\delta(\mathrm{ppm})=164.18(\mathrm{Ct}), 156.77,154.59,149.54,148.32,141.69,137.74,130.85,129.95,129.07,128.80$, 128.27, 127.64, 125.08, 120.76. Anal. Calcd. for $\mathrm{C}_{23} \mathrm{H}_{14} \mathrm{~N}_{7} \mathrm{O}_{3} \mathrm{Re}$ (622.61) C 44.37, H 2.27, N 15.75. Found: C $44.45, \mathrm{H} 2.31, \mathrm{~N} 15.82 \%$.

fac-[Re(phen) $\left.(\mathrm{CO})_{3}(\mathbf{2}-\mathrm{PTZ})\right]: 0.072 \mathrm{~g}, 91 \%$. ESI-MS $(\mathrm{m} / \mathrm{z})=580[\mathrm{M}+\mathrm{H}]^{+} .{ }^{1} \mathrm{H}-\mathrm{NMR} 400 \mathrm{MHz}, \mathrm{DMSO}-d^{6} \delta$ $(\mathrm{ppm})=9.57(\mathrm{~m}, 2 \mathrm{H}), 8.97(\mathrm{~m}, 2 \mathrm{H}), 8.48(\mathrm{~m}, 1 \mathrm{H}), 8.30(\mathrm{~s}, 2 \mathrm{H}), 8.12(\mathrm{~m}, 2 \mathrm{H}), 7.69(\mathrm{~m}, 1 \mathrm{H}), 7.53(\mathrm{~m}, 1 \mathrm{H})$, $7.24(\mathrm{~m}, 1 \mathrm{H}) .{ }^{13} \mathrm{C}-\mathrm{NMR} 100 \mathrm{MHz}, \mathrm{DMSO}-d^{6} \delta(\mathrm{ppm})=163.85(\mathrm{Ct}), 155.31,150.34,149.38,147.29,137.69$, $131.24,128.69,127.70,124.32,122.35$. Crystals suitable for X-ray analysis (identified as fac$\left[\mathrm{Re}\left(\right.\right.$ phen) $\left.(\mathrm{CO})_{3}(2-\mathrm{PTZ})\right] \cdot \mathrm{CH}_{2} \mathrm{Cl}_{2}, \mathrm{C}_{22} \mathrm{H}_{14} \mathrm{~N}_{7} \mathrm{Cl}_{2} \mathrm{O}_{3} \mathrm{Re}$ ) were obtained by slow diffusion of diethyl ether into a solution of the complex in dichloromethane. Anal. Calcd. for $\mathrm{C}_{22} \mathrm{H}_{14} \mathrm{~N}_{7} \mathrm{Cl}_{2} \mathrm{O}_{3} \mathrm{Re}(681.50) \mathrm{C} 38.77, \mathrm{H}$ 2.07, N 14.39. Found: C 38.85, H 2.12, N 14.31\%.

fac-[Re(bipy)(CO) $\left.)_{3}(\mathbf{2}-\mathrm{PTZ})\right]: 0.058 \mathrm{~g}, 58 \%$. ESI-MS $(\mathrm{m} / \mathrm{z})=573[\mathrm{M}+\mathrm{H}]^{+} .{ }^{1} \mathrm{H}-\mathrm{NMR} 400 \mathrm{MHz}, \mathrm{DMSO}-\mathrm{d}^{6} \delta$ $(\mathrm{ppm})=9.14\left(\mathrm{~d}, 2 \mathrm{H}, J_{\mathrm{H}-\mathrm{H}}=4.8 \mathrm{~Hz}\right), 8.37\left(\mathrm{~d}, 2 \mathrm{H}, J_{\mathrm{H}-\mathrm{H}}=8.4 \mathrm{~Hz}\right), 8.33(\mathrm{t}, 2 \mathrm{H}), 7.76\left(\mathrm{~d}, 1 \mathrm{H}, J_{\mathrm{H}-\mathrm{H}}=8 \mathrm{~Hz}\right), 7.29$ $(\mathrm{s}, 1 \mathrm{H}) .{ }^{13} \mathrm{C}-\mathrm{NMR} 100 \mathrm{MHz}, \mathrm{DMSO}-d^{6} \delta(\mathrm{ppm})=163.50(\mathrm{Ct}), 156.18,154.05,149.94,148.85,141.19$, $137.38,128.55,124.52,124.01,122.04$. Crystals suitable for X-ray analysis (identified as fac[Re(CO) ${ }_{3}\left(\right.$ bipy)(2-PTZ)], $\mathrm{C}_{19} \mathrm{H}_{12} \mathrm{~N}_{7} \mathrm{O}_{3} \mathrm{Re}$ ) were obtained by slow diffusion of diethyl ether into a solution of the complex in dichloromethane. Anal. Calcd. for $\mathrm{C}_{19} \mathrm{H}_{12} \mathrm{~N}_{7} \mathrm{O}_{3} \mathrm{Re}$ (572.56) C 39.86, H 2.11, N 17.12. Found: C 39.79, H 2.09, N 17.09\%.

\section{General Procedure for the Preparation of the Cu-POP $f a c-\left[\operatorname{Re}(b i p y)(C O)_{3} \mathrm{~L}\right]-\mathrm{Type}$ Complexes}

In a $100 \mathrm{~mL}$ Schlenck tube protected from light and under an Ar atmosphere, $0.041 \mathrm{~g}$ of $\left[\mathrm{Cu}\left(\mathrm{CH}_{3} \mathrm{CN}\right)_{4}\right]\left[\mathrm{BF}_{4}\right]$ 
(1.0 mmol, 1 equiv) were dissolved in $10 \mathrm{~mL}$ of dichloromethane. Once the $\mathrm{Cu}(\mathrm{I})$ salt was completely dissolved, $0.070 \mathrm{~g}(0.130 \mathrm{mmol}, 1$ equiv) of the diphosphine POP was added to the solution. The mixture was left to stir at r.t. for $2 \mathrm{~h}$, after which time $5.0 \mathrm{~mL}$ of a dichloromethane solution containing 1 equiv. of the appropriate $\operatorname{Re}(\mathrm{I})$ complex, $f a c$ - $\left[\operatorname{Re}(\mathbf{b i p y})(\mathrm{CO})_{3}(\mathbf{2}\right.$-PTZ $\left.)\right]$ or $f a c-\left[\operatorname{Re}(\mathbf{b i p y})(\mathrm{CO})_{3}(\mathbf{2}-\mathbf{Q T Z})\right]$ was added dropwise over a period of $30 \mathrm{~min}$. After two hours of stirring at r.t., the solvent was removed in vacuo until the total volume was reduced to ca. $5.0 \mathrm{~mL}$. The dropwise addition of ca. $20 \mathrm{~mL}$ of diethyl ether caused the precipitation of a yellow microcrystalline powder that was separated from the mother liquors by suction filtration under Ar atmosphere.

$[\boldsymbol{R e}-(\mathbf{2}-P T Z)-C u]^{+} 0.201$ g, 76\%. ESI-MS $(\mathrm{m} / \mathrm{z})=1174[\mathrm{M}]^{+} .{ }^{1} \mathrm{H}-\mathrm{NMR} 400 \mathrm{MHz}, \mathrm{CDCl}_{3} \delta(\mathrm{ppm})=8.91(\mathrm{~d}$, $\left.2 \mathrm{H}, J_{H-H}=5.2 \mathrm{~Hz}\right), 8.73\left(\mathrm{~d}, 2 \mathrm{H}, J_{H-H}=8.3 \mathrm{~Hz}\right), 8.13(\mathrm{~m}, 2 \mathrm{H}), 7.78(\mathrm{~m}, 3 \mathrm{H}), 7.40(\mathrm{~m}, 2 \mathrm{H}), 7.28-7.12(\mathrm{~m}$, 20H), $6.96(\mathrm{~m}, 5 \mathrm{H}), 6.58(\mathrm{~m}, 2 \mathrm{H}), 6.49(\mathrm{~m}, 4 \mathrm{H}) .{ }^{13} \mathrm{C}-\mathrm{NMR} 100 \mathrm{MHz}, \mathrm{CDCl}_{3} \delta(\mathrm{ppm})=157.27(\mathrm{Ct}), 155.75$, $151.47,147.96,144.85,139.76,137.51,133.36,133.10,131.00,130.46,130.20,129.39,129.05,128.61$, 127.60, 125.77, 124.02, 123.79, 123.47, 123.14, 121.16, 119.13, 118.70. Crystals suitable for X-ray analysis (identified as $f a c$ - $\left[\mathrm{Re}\left(\right.\right.$ bipy) $\left.(\mathrm{CO})_{3}(2-\mathrm{PTZ}) \mathrm{Cu}(\mathrm{POP})\right]\left[\mathrm{BF}_{4}\right] \cdot 2 \mathrm{Et}_{2} \mathrm{O}, \mathrm{C}_{63} \mathrm{H}_{60} \mathrm{~N}_{7} \mathrm{O}_{6} \mathrm{P}_{2} \mathrm{BF}_{4} \mathrm{CuRe}$ ) were obtained by slow diffusion of diethyl ether into a solution of the complex in dichloromethane. Anal. Calcd. for $\mathrm{C}_{63} \mathrm{H}_{60} \mathrm{~N}_{7} \mathrm{O}_{6} \mathrm{P}_{2} \mathrm{BF}_{4} \mathrm{CuRe}(1409.67) \mathrm{C} 53.68, \mathrm{H} 4.29, \mathrm{~N}$ 6.95. Found: C 53.72, H 4.34, N 6.91\%.

$[\boldsymbol{R e}-(\mathbf{2}-\mathbf{Q T Z})-\mathbf{C u}]^{+} 0.187 \mathrm{~g}, 85 \%$. ESI-MS $(\mathrm{m} / \mathrm{z})=1224[\mathrm{M}]^{+} .{ }^{1} \mathrm{H}-\mathrm{NMR} 400 \mathrm{MHz}, \mathrm{CDCl}_{3} \delta(\mathrm{ppm})=8.96(\mathrm{~d}$, $\left.2 \mathrm{H}, J_{H-H}=4.8 \mathrm{~Hz}\right), 8.71\left(\mathrm{~d}, 2 \mathrm{H}, J_{H-H}=6.8 \mathrm{~Hz}\right), 8.35\left(\mathrm{~d}, 1 \mathrm{H}, J_{H-H}=7.9 \mathrm{~Hz}\right), 7.88\left(\mathrm{~d}, 1 \mathrm{H}, J_{H-H}=8.8 \mathrm{~Hz}\right), 7.80$ (m, 2H), 7.43-7.20 (m, 19H), $7.11(\mathrm{~m}, 3 \mathrm{H}), 7.00(\mathrm{~m}, 2 \mathrm{H}), 6.90(\mathrm{~m}, 4 \mathrm{H}), 6.83(\mathrm{~m}, 4 \mathrm{H}), 6.59(\mathrm{~m}, 2 \mathrm{H}), 6.41(\mathrm{~m}$, $4 \mathrm{H}) .{ }^{13} \mathrm{C}-\mathrm{NMR} 100 \mathrm{MHz}, \mathrm{CDCl}_{3} \delta(\mathrm{ppm})=158.57(\mathrm{Ct}), 156.54,152.56,145.77,140.81,138.80,134.52$, 134.32, 134.24, 134.15, 131.93, 131.85, 131.77, 131.52, 131.05, 130.52, 130.39, 129.76, 129.37, 128.66, $128.61,128.20,128.15,128.10,127.66,127.51,126.97,124.99,124.88,120.07,119.15$. Crystals suitable for $\mathrm{X}$-ray analysis (identified as $f a c$ - $\left[\mathrm{Re}(\mathrm{bipy})(\mathrm{CO})_{3}(2-\mathrm{QTZ}) \mathrm{Cu}(\mathrm{POP})\right]\left[\mathrm{BF}_{4}\right] \cdot 1.67 \mathrm{CH}_{2} \mathrm{Cl}_{2}$ $\mathrm{C}_{60.67} \mathrm{H}_{45.33} \mathrm{~N}_{7} \mathrm{O}_{4} \mathrm{Cl}_{3.33} \mathrm{P}_{2} \mathrm{BF}_{4} \mathrm{CuRe}$ were obtained by slow diffusion of diethyl ether into a solution of the complex in dichloromethane. Anal. Calcd. for for $\mathrm{C}_{60.67} \mathrm{H}_{45.33} \mathrm{~N}_{7} \mathrm{O}_{4} \mathrm{Cl}_{3.33} \mathrm{P}_{2} \mathrm{BF}_{4} \mathrm{CuRe}$ (1453.03) C 50.15, $\mathrm{H}$ 3.14, N 6.75. Found: C 50.19, H 3.19, N 6.71\%.

\section{Ion-Dependent Emission Studies.}

In the ion-dependent emission studies, a $10 \mathrm{~mL}$ stock solution of $f a c$ - $\left[\mathrm{Re}(\mathbf{p h e n})(\mathrm{CO})_{3}(\mathbf{2}-\mathbf{Q T Z})\right]$ complex $\left(1,55^{*} 10^{-4} \mathrm{M}\right)$ in $\mathrm{CH}_{3} \mathrm{CN}$ was prepared. $2 \mathrm{~mL}$ of the stock solution were then transferred to a quartz cuvette and the emission spectrum of the solution was measured after successive additions $(10 \mu \mathrm{L}$ aliquots for 20 additions with $\mathrm{Zn}\left(\mathrm{ClO}_{4}\right)_{2}$ in $\mathrm{CH}_{3} \mathrm{CN}, 5,37 * 10^{-4} \mathrm{M} ; 10 \mu \mathrm{L}$ aliquots for 60 additions with $\mathrm{Cd}\left(\mathrm{ClO}_{4}\right)_{2}$ in $\mathrm{CH}_{3} \mathrm{CN}$, $2,38 * 10^{-4} \mathrm{M} ; 5 \mu \mathrm{L}$ aliquots for 20 additions with $\mathrm{Cu}\left(\mathrm{ClO}_{4}\right)_{2}$ in $\left.\mathrm{CH}_{3} \mathrm{CN}, 2,69 * 10^{-4} \mathrm{M}\right)$ of the ion solution at 2 min intervals.

fac-[Re (bipy)(CO) $\left.)_{3}(\mathbf{2}-\mathbf{Q T Z})\right]$ complex, a $10 \mathrm{~mL}$ stock solution $\left(1,61 * 10^{-4} \mathrm{M}\right)$ in $\mathrm{CH}_{3} \mathrm{CN}$ was prepared. $2 \mathrm{~mL}$ 
of the stock solution was transferred to a quartz cuvette and the emission spectrum of the solution was measured after successive additions $\left(10 \mu \mathrm{L}\right.$ aliquots for 20 additions with $\mathrm{Zn}\left(\mathrm{ClO}_{4}\right)_{2}$ in $\mathrm{CH}_{3} \mathrm{CN}, 5,37 * 10^{-4} \mathrm{M}$; $10 \mu \mathrm{L}$ aliquots for 60 additions with $\mathrm{Cd}\left(\mathrm{ClO}_{4}\right)_{2}$ in $\mathrm{CH}_{3} \mathrm{CN}, 2,38^{*} 10^{-4} \mathrm{M} ; 100 \mu \mathrm{L}$ aliquots for 3 additions with $\mathrm{Cu}\left(\mathrm{ClO}_{4}\right)_{2}$ in $\left.\mathrm{CH}_{3} \mathrm{CN}, 2,69 * 10^{-4} \mathrm{M}\right)$ of the ion solution at 2 min intervals.

fac-[Re (phen)(CO) $)_{3}(\mathbf{2}$-PTZ)] $)$ complex $\left(1,68 * 10^{-4} \mathrm{M}\right)$ in $\mathrm{CH}_{3} \mathrm{CN}$ was prepared. $2 \mathrm{~mL}$ of the stock solution was transferred to a quartz cuvette and the emission spectrum of the solution was measured after successive additions $\left(10 \mu \mathrm{L}\right.$ aliquots for 28 additions with $\mathrm{Zn}\left(\mathrm{ClO}_{4}\right)_{2}$ in $\mathrm{CH}_{3} \mathrm{CN}, 5,37 * 10^{-4} \mathrm{M} ; 10 \mu \mathrm{L}$ aliquots for 60 additions with $\mathrm{Cd}\left(\mathrm{ClO}_{4}\right)_{2}$ in $\mathrm{CH}_{3} \mathrm{CN}, 2,38^{*} 10^{-4} \mathrm{M} ; 100 \mu \mathrm{L}$ aliquots for 5 additions with $\mathrm{Cu}\left(\mathrm{ClO}_{4}\right)_{2}$ in $\mathrm{CH}_{3} \mathrm{CN}$, $\left.2,69 * 10^{-4} \mathrm{M}\right)$ of the ion solution at 2 min intervals.

fac-[Re (bipy) $\left.(\mathrm{CO})_{3}(\mathbf{2}-\mathrm{PTZ})\right]$ complex, a $10 \mathrm{~mL}$ stock solution $\left(1,75^{*} 10^{-4} \mathrm{M}\right)$ in $\mathrm{CH}_{3} \mathrm{CN}$ was prepared. $2 \mathrm{~mL}$ of the stock solution was transferred to a quartz cuvette and the emission spectrum of the solution was measured after successive additions $\left(10 \mu \mathrm{L}\right.$ aliquots for 23 additions with $\mathrm{Zn}\left(\mathrm{ClO}_{4}\right)_{2}$ in $\mathrm{CH}_{3} \mathrm{CN}, 5,37 * 10^{-4} \mathrm{M}$; $10 \mu \mathrm{L}$ aliquots for 50 additions with $\mathrm{Cd}\left(\mathrm{ClO}_{4}\right)_{2}$ in $\mathrm{CH}_{3} \mathrm{CN}, 2,38^{*} 10^{-4} \mathrm{M} ; 100 \mu \mathrm{L}$ aliquots for 6 additions with $\mathrm{Cu}\left(\mathrm{ClO}_{4}\right)_{2}$ in $\left.\mathrm{CH}_{3} \mathrm{CN}, 2,69 * 10^{-4} \mathrm{M}\right)$ of the ion solution at 2 min intervals.

\section{X-ray crystallography.}

Crystal data and collection details for $f a c-\left[\operatorname{Re}(\right.$ bipy $\left.)(\mathrm{CO})_{3}(2-\mathrm{PTZ})\right], \quad f a c-\left[\operatorname{Re}(\right.$ phen $)(\mathrm{CO})_{3}(2$ $\mathrm{PTZ})] \cdot \mathrm{CH}_{2} \mathrm{Cl}_{2}, \quad f a c$ - $\left[\mathrm{Re}(\mathrm{phen})(\mathrm{CO})_{3}(2-\mathrm{QTZ})\right] \cdot 0.5 \mathrm{CH}_{2} \mathrm{Cl}_{2}, \quad \quad f a c$ - $\left[\mathrm{Re}(\right.$ bipy $)(\mathrm{CO})_{3}(2-$ $\mathrm{PTZ})(\mathrm{CuPOP})]\left[\mathrm{BF}_{4}\right] \cdot 2 \mathrm{Et}_{2} \mathrm{O} \quad$ and $\quad f a c-\left[\mathrm{Re}(\mathrm{bipy})(\mathrm{CO})_{3}(2-\mathrm{QTZ})(\mathrm{CuPOP})\right]\left[\mathrm{BF}_{4}\right] \cdot 1.67 \mathrm{CH}_{2} \mathrm{Cl}_{2} \quad$ are reported in Table S4, supporting information. The diffraction experiments were carried out on a Bruker APEX II diffractometer equipped with a CCD detector and using Mo-K $\alpha$ radiation. Data were corrected for Lorentz polarization and absorption effects (empirical absorption correction $\mathrm{SADABS}^{22}$. Structures were solved by direct methods and refined by full-matrix least-squares based on all data using $F^{2}{ }^{23} \mathrm{H}$-atoms were placed in calculated positions, and refined isotropically using a riding model. All non-hydrogen atoms were refined with anisotropic displacement parameters.

The asymmetric unit of the unit cell of $f a c$ - $\left[\mathrm{Re}(\mathrm{phen})(\mathrm{CO})_{3}(2-\mathrm{QTZ})\right] \cdot 0.5 \mathrm{CH}_{2} \mathrm{Cl}_{2}$ contains two independent $f a c$ - $\left[\mathrm{Re}(\right.$ phen $\left.)(\mathrm{CO})_{3}(2-\mathrm{QTZ})\right]$ molecules and one $\mathrm{CH}_{2} \mathrm{Cl}_{2}$ molecule.

One of the two $\mathrm{Et}_{2} \mathrm{O}$ molecules of $f a c$ - $\left[\mathrm{Re}(\right.$ bipy $\left.)(\mathrm{CO})_{3}(2-\mathrm{PTZ})(\mathrm{CuPOP})\right]\left[\mathrm{BF}_{4}\right] \cdot 2 \mathrm{Et}_{2} \mathrm{O}$ is disordered. Thus, it has been split into two positions and refined using one occupancy parameter per disordered group. The geometries of the $\mathrm{Et}_{2} \mathrm{O}$ molecules have been restrained to be similar (SAME line in SHELXL; s.u. 0.02) and their C-C and C-O distances restrained to 1.53 and $1.43 \AA$, respectively (DFIX line in SHELXL; s.u. 0.01). Similar $U$ restraints (SIMU line in SHELXL; s.u. 0.01) were applied to all the C, O, F and $\mathrm{N}$ atoms. Some high residual electron densities remain close to the Re atoms $(0.95 \AA$ from $\operatorname{Re}(1))$ due to absorption effects. 
The asymmetric unit of the unit cell of $f a c$ - $\left[\mathrm{Re}(\mathrm{bipy})(\mathrm{CO})_{3}(2-\mathrm{QTZ})(\mathrm{CuPOP})\right]\left[\mathrm{BF}_{4}\right] \cdot 1.67 \mathrm{CH}_{2} \mathrm{Cl}_{2}$ contains three independent $f a c-\left[\operatorname{Re}(\text { bipy })(\mathrm{CO})_{3}(2-\mathrm{QTZ})(\mathrm{CuPOP})\right]^{+}$cations, three $\left[\mathrm{BF}_{4}\right]^{-}$anions and five $\mathrm{CH}_{2} \mathrm{Cl}_{2}$ molecules. Some high residual electron densities remain close to the Re atoms $(0.85$ and $0.76 \AA$ from $\operatorname{Re}(1))$ due to absorption effects. .

CCDC-1422231 (for fac-[Re(bipy)(CO) 3 2-PTZ)]), -1422232 (for fac-[Re(phen)(CO) 3 (2-PTZ)]), 1422233 for (for $f a c$-[Re(phen)(CO) $3(2-\mathrm{QTZ})]$ ), -1422234 (for [Re-(2-PTZ)-Cu]) -1422235 (for $[\operatorname{Re}-(2-\mathrm{QTZ})-\mathrm{Cu}])$ contain the supplementary crystallographic data for this paper. These data can be obtained free of charge from The Cambridge Crystallographic Data Centre via www.ccdc.cam.ac.uk/data request/cif.

Supporting Information: X-ray crystallographic data for the complexes $f a c$ - $\left[\operatorname{Re}(\right.$ bipy $\left.)(\mathrm{CO})_{3}(2-\mathrm{PTZ})\right]$, $f a c$ $\left[\operatorname{Re}(\right.$ phen $\left.\left.)(\mathrm{CO})_{3}(2-\mathrm{PTZ})\right]\right), \quad f a c$ - $\left.\left.\left.\left[\operatorname{Re}(\mathrm{phen})(\mathrm{CO})_{3}(2-\mathrm{QTZ})\right]\right), \quad[\mathrm{Re}-(2-\mathrm{PTZ})-\mathrm{Cu}]^{+}\right) \quad[\operatorname{Re}-(2-\mathrm{QTZ})-\mathrm{Cu}]\right)$ in $\mathrm{CIF}$ format. IR and $\operatorname{NMR}\left({ }^{1} \mathrm{H},{ }^{13} \mathrm{C}\right)$ spectra of all the Re(I) based species. UV-vis absorption, emission spectra recorded at r.t. and at $77 \mathrm{~K}$, Emission titrations, Stern Volmer plots. This material is available free of charge via the Internet at http://pubs.acs.org

\section{Acknowledgments}

The Toso Montanari Foundation and the Australian Research Council (grant number: FT1301000033) are gratefully acknowledged for the financial support. 


\section{Table of Contents:}

\section{Graphics:}

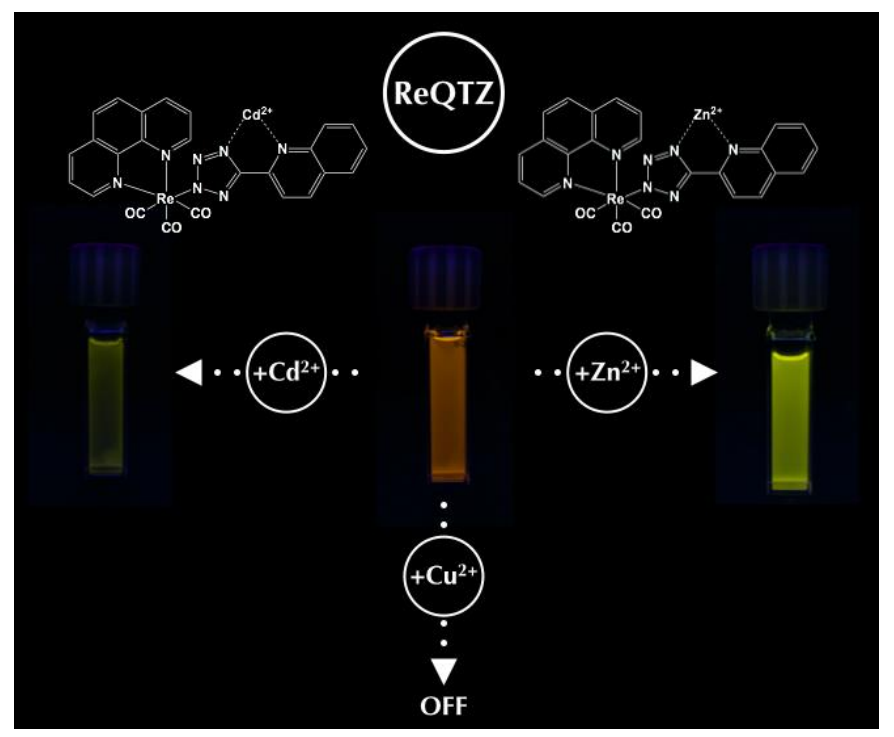

\section{Text:}

The design, the preparation and the characterization of four new $\operatorname{Re}(\mathrm{I})$ tetrazolato complexes together with the study of their luminescent sensing abilities toward $\mathrm{Zn}(\mathrm{II}), \mathrm{Cd}(\mathrm{II})$ and $\mathrm{Cu}(\mathrm{II})$ are described herein. 


\section{References}

[1] a) R. A. Kirgan, B. P. Sullivan and D. P. Rillema, Top. Curr. Chem., 2007, 281, 45-100, b) A. Kumar, S. Sun and A. Lees, Top. Organomet. Chem., 2010, 29, 1-35.

[2] a) K. Y. Zhang and K. K.-W. Lo, Chemosensing and Diagnostics. In Coordination and Organometallic Chemistry (Volume 8) of Comprehensive Inorganic Chemistry II; V. W.-W. Yam Ed.; Elsevier: Amsterdam, 2013, 657-732; b) K. K.-W. Lo and S. P.-Y. Li, RSC Adv., 2014, 4, 10560-10585; c) K. K.-Wing Lo, K. Y. Zhang and S. P.-Y. Li, Eur. J. Inorg. Chem., 2011, 35513568 , and references cited therein.

[3] a) V. Fernandez-Moreira, F. L. Thorp-Greenwood and M. P. Coogan, Chem. Commun., 2010, 46, 186-202 and references cited therein. See also: b) L. A. Mullice and S. J. A. Pope, Dalton Trans., 2010, 39, 5908-5917; c) M.-W. Louie, H.-W. Liu, M. H.-C. Lam, T.-C. Lau, and K. K.-W. Lo, Organometallics, 2009, 28, 4297-4307.

[4] a) M. V. Werrett, D. Chartrand, G. D. Gale, G. S. Hanan, J. G. MacLellan, M. Massi, S. Muzzioli, P. Raiteri, B. W. Skelton, M. Silberstein and S. Stagni, Inorg. Chem., 2011, 50, 12291241; b) D. S. Silvester, S. Uprety, P. J. Wright, M. Massi, S. Stagni and S. Muzzioli, J. Phys. Chem. C, 2012, 116, 7327-7333; c) P. J. Wright, S. Muzzioli, M. V. Werrett, P. Raiteri, B. W. Skelton, D. S. Silvester, S. Stagni and M. Massi, Organometallics, 2012, 31, 7566-7578; d) P. J. Wright, S. Muzzioli, B. W. Skelton, P. Raiteri, J. Lee, G. Koutsantonis, D. S. Silvester, S. Stagni, and M. Massi, Dalton Trans., 2013, 42, 8188-8191; e) P. J. Wright, M. G. Affleck, S. Muzzioli, B. V. Skelton, P. Raiteri, D. S. Silvester, S. Stagni and M. Massi, Organometallics, 2013, 32, 37283737.

[5] a) M. V. Werrett, S. Muzzioli, P. J. Wright, A. Palazzi, P. Raiteri, S. Zacchini, M. Massi and S. Stagni, Inorg. Chem., 2014, 53, 229-243; b) M. V. Werrett, G. S. Huff, S. Muzzioli, V. Fiorini, S. Zacchini, B. W. Skelton, A. Maggiore, J. M. Malicka, M. Cocchi, K. C. Gordon, S. Stagni and M. Massi, Dalton Trans., 2015, 44, 8379-8393.

[6] C. A. Bader, R. D. Brooks, Y. S. Ng, A. Sorvina, M. V. Werrett, P. J. Wright, A. G. Anwer, D. A. Brooks, S. Stagni, S. Muzzioli, M. Silberstein, B. W. Skelton, E. M. Goldys, S. E. Plush, T. Shandala and M. Massi, RSC Adv., 2014, 4, 16345-16351.

[7] Z. Liu, W. He, Z. Guo, Chem. Soc. Rev., 2013, 42, 1568-1600, and references cited therein. 
[8] a) W. G. Finnegan, R. A. Henry and R. Lofquist, J. Am. Chem. Soc., 1958, 80, 3908-3911; b) K. Koguro, T. Oga, S. Mitsui and R. Orita, Synthesis, 1998, 910-913.

[9] R. Butler and V. Garvin, J. Chem. Soc., Perkin Trans. 1, 1981,390-393.

[10] a) A. Palazzi, S. Stagni, S. Bordoni, M. Monari and S. Selva, Organometallics, 2002, 21, 3774-3781; b) S. Stagni, A. Palazzi, S. Zacchini, B. Ballarin, C. Bruno, M. Marcaccio, F. Paolucci, M. Monari, M. Carano and A. J. Bard, Inorg. Chem., 2006, 45, 695-709.

[11] C. Femoni, S. Muzzioli, A. Palazzi, S. Stagni, S. Zacchini, F. Monti, G. Accorsi, M. Bolognesi, N. Armaroli, M. Massi, G. Valenti and M. Marcaccio, Dalton Trans., 2013, 42, 997-1010.

[12] (a) R. Czerwieniec, J. Yu and H. Yersin, Inorg. Chem., 2011, 50, 8293-8301; (b) U. Monkowius, S. Ritter, B. König, M. Zabel and H. Yersin, Eur. J. Inorg. Chem., 2007, 4597-4606; (c) S.-H. Kuang, D. G. Cuttell, D. R. McMillin, P. E. Fanwick and R. A. Walton, Inorg. Chem., 2002, 41, 3313-3322; (d) D. G. Cuttell, S.-H. Kuang, P. E. Fanwick, D. R. McMillin and R. A. Walton, J. Am. Chem. Soc., 2002, 124, 6-7.

[13] a) Q. Zhang, Q. Zhou, Y. Cheng, L. Wang, D. Ma, X. Jing and F. Wang, Adv. Funct. Mater., 2006, 16, 1203-1208; b) L. Yang, J.-K. Feng, A.-M. Ren, M. Zhang, Y.-G. Ma, and X.-D. Liu, Eur. J. Inorg. Chem., 2005, 1867-1879.

[14] a) P. W. N. M. van Leeuwen, P. C. J. Kamer, J. N. H. Reek and P. Dierkes, Chem. Rev., 2000, 100, 2741-2770; b) L. A. van der Veen, P. K. Keeven, G. C. Schoemaker, J. N. H. Reek, P. C. J. Kamer, P. W. N. M. van Leeuwen, M. Lutz and A. L. Spek, Organometallics, 2000, 19, 872-883; c) P. C. J. Kamer, P. W. N. M. van Leeuwen and J. N. H. Reek, Acc. Chem. Res., 2001, 34, 895904; d) M. Kranenburg, Y. E. M. van der Burgt, P. C. J. Kamer, P. W. N. M. van Leeuwen, K. Goubitz and K. Fraanje, Organometallics, 1995, 14, 3081-3089.

[15] J. V. Caspar and T. J. Meyer, J. Phys. Chem., 1983, 87, 952-957.

[16] N. Armaroli, G. Accorsi, F. Cardinali and A. Listorti, Top. Curr. Chem., 2007, 281, 69-115 and references cited therein.

[17] G. J. Kubas, Inorg. Synth., 1979, 19, 90-92.

[18] G. A. Crosby and J. N Demas,. J. Phys. Chem., 1971, 75, 991-1024.

[19] D. F. Eaton, Pure Appl. Chem., 1988, 60, 1107-1114. 
[20] K. Nakamura, Bull. Chem. Soc. Jpn., 1982, 55, 2697-2705.

[21] R. N. Butler, Tetrazoles. In “Comprehensive Heterocyclic Chemistry II”; Storr, R. C., Ed.; Pergamon Press: Oxford, U.K., 1996; Vol. 4, pp 621-678, and references cited therein.

[22] G. M. Sheldrick, SADABS, Program for Empirical Absorption Correction, University of Göttingen, Germany, 1996.

[23] G. M. Sheldrick, SHELX97-Program for the refinement of Crystal Structure, University of Göttingen, Germany, 1997. 